\title{
Studies of the Genotoxic and Histopathological effects of the Organophosphorous insecticide 'Profenofos' on white rats.
}

\author{
Fatma M. Hammam* and Eman M. Abd el Mottaleb** \\ *Department Of Mammalian Toxicology, Central Agricultural Pesticides Laboratory, \\ Agricultural Research Centre, Ministry Of Agriculture \\ **Department of pathology, Animal Health Research Institute
}

\begin{abstract}
Genotoxic effects of agricultural chemicals are of special concern because of their generally irreversible effects and the long latency associated with their manifestation. These effects include heritable genetic diseases, carcinogenesis, reproductive dysfunction and birth defects. The present study was carried out to investigate the effect of the organophosphorous insecticide "profenofos" on white albino rats. The rats were treated for 28 days with three different doses of profenofos (1/20 LD50, 1/40 LD50, and 1/80 LD50). Then the animals were left without treatments for 14 days for possible recovery. The genotoxic effect of the pesticide was evaluated by using the micronucleus assay in the bone marrow and polymorphism of glutathione S-transferase (GST) by polymerase chain reaction (PCR). The results demonstrated that the treatment with profenofos caused a significant increase in the frequencies of micronucleated polychromatic erythrocytes. Results of polymorphism of both GSTM1 and GSTT1 showed positive genotype in the control group. While the results of GSTT1 polymorphism in the treated rats showed positive genotype in all doses of profenofos. The GSTM1 polymorphism showed positive genotype in the high and medium doses (1/20 LD50 and 1/40 LD50) but not in the low dose (1/80 LD50), where the GSTM1 was null (negative) genotype. After the recovery period the polymorphism of GSTM1 and GSTT1 was found to be positive genotype, except with the low dose (1/80 LD50) showed null genotype for GSTM1 gene. The histopathological data showed that profenofos exhibited histopathological changes in liver, kidney, spleen and tests. Liver showed hepatic cell damage with degenerative changes. The kidney showed heamorrhages, edema, necrosis and glomeruli shrinkage. The spleen showed slight deplesion of the lymphocytes of the white pulp. The tests showed interstitial edema and severe necrosis of spermatogenesis. From these results we concluded that the profenofos exert genotoxic and histopathological effects on albino white rats.
\end{abstract}

Key words: Profenofos, Micronucleus, GSTM1, GSTT1, Organophosphorous.

\section{Introduction}

Recently, the pesticides problem has been in the focus of public interest. While the usage of pesticides is still the most effective and accepted means to protect plants from the pests and to increases productivity. The wide spread of pesticides is connected with serious problems of pollution and health hazards (Fahmy and Darwish, 2002). Genotoxic effects are considered among the most serious side effects of pesticides. The effects include heritable genetic diseases, carcinogenesis, reproductive dysfunction and birth defects.
Several studies all over the world showed the cancer risk after exposure to insecticides. (Wild, 1978 \& Iarc, 1991).

1-Mutagenic effect of pesticides
(Micronucleus assay): The micronucleus test has been used as an in-vivo cytogenetic test to estimate the clastogenic potential of chemicals. Micronuclei (MN) are acentric chromosome fragments or whole chromosomes left behind during mitotic cellular division and appear in the 
cytoplasm of interphase cells as small additional nuclei. The micronucleus assay has shown to be a reliable and sensitive biomarker (Surralles et al., 1992 ; TitenkoHolland et al., 1994 ; Kirsch-Volders et al., 1997) also for human biomonitoring (Bolongesi et al.,1993 ; Fenech 1993 ; Gutierrez et al., 1997 ; Surralles et al., 1997) being an adequate alternative to the in vitro chromosomal aberration test (Miller et al., 1997)

The effect of pesticides in flower cultivation in Italy was studied by Bolognesi et al. (1993). The frequency of micronuclei in peripheral lymphocytes has been evaluated in 71 floriculturists and in a control group of 75 healthy blood donors living in the same area. The frequencies of micronucleated lymphocytes were significantly higher in females than in males in both exposed and control groups

The micronucleus formation in human lymphocytes as a biomarker of genotoxicity both in vitro and in vivo was studied by Titenko-Holland et al. (1997); they found a significant increase in micronucleated cells under the effect of high dose levels.

Davies et al. (1998) evaluated micronuclei in peripheral blood lymphocytes from British Colombia seasonal farm workers and controls using the cytokinesis-block technique. They found an elevated frequency of micronucleated cells in workers with the longest history of employment compared to those with short employment history. In another study, the cytogenetic damage was recorded in floriculturists of Morelos State, Mexico, exposed to pesticides using biological tests based on micronuclei (MN) in exfoliated cells of the buccal mucosa (Gomez-Arroyo et al., 2000). They found that the MN frequencies in the exposed workers were three times higher than in the non-exposed workers. Many studies have demonstrated the efficiency of the micronucleus assay to detect DNA damage produced under the effect of pesticides, both in cell cultures as whole blood or isolated lymphocytes (Holland et al., 2002 ;Abdel-Aziz, Maii., 2004).

The genotoxic effect of pesticides on rat bone marrow cells was studied by many authors using the micronucleus assay (Hammam and El-Khatib., 2004; Hammam,
2004 ; D' Souza et al., 2005). They found significant increase in the induction of polychromatic erythrocytes micronucleus (PCEM). Also, Zhou et al. (2005) evaluated the effect of carbofuran and its four metabolites on mice by micronucleus test; the results showed that some metabolites of carbofuran " 3-hydro and nitro-carbofuran" could induce micronucleus formation.

Several studies have addressed cytogenetic changes in pesticides-exposed workers (Bahali et al., 2006; Leucero et al., 2000; Pastor et al., 2001).The first study found that exposed individuals exhibited cyotogenetic damage with increased frequencies of binucleated cells with micronucleus. On the other hand the other two studies found no statistically significant difference in micronucleus prevalence between pesticide-exposed and control individuals.

\section{2- Mutagenic effect of pesticides (Glutathione S-transferase M1(GSTM1) and Glutathione S-transferase T1 (GSTT1):}

Human genetic polymorphisms in metabolic activation and detoxification pathways appear to be important sources of inter-individual variation in susceptibility to cancer. Individuals who inherit the at-risk alleles of genes for enzymes such as glutathione S-transferases (GST) may fail to be protected against carcinogens in cigarette smoke, diet, industrial processes, and environmental pollution (Bell et al., 1993). Two distinct supergene families encode proteins with glutathione $\mathrm{S}$ transferase (GST) activity; firstly, at least 16 genes encode proteins expressed in tissue cytosols and secondly, at least six genes are expressed in membranes (Hayes and Strange 2000). In humans, eight distinct gene families encode these soluble GST; alpha on chromosome $6, \mathrm{mu}$ on chromosome 1 , theta on chromosome 22 , pi on chromosome 11 , zeta on chromosome 14, sigma on chromosome 4, kappa (chromosomal location not known) and chi (also called omega) on chromosome 10. The kappa enzymes while probably soluble are expressed in the mitochondria. Polymorphism has been described in many genes in these families though to date, most attention has focused on allelism in the mu, 
theta and pi families (Rebbeck, 1997 ; Hayes and Strange 2000). The different GST enzymes have classically been viewed as part of cell defence against numerous harmful chemicals produced endogenously and in the environment. The general reaction of GST enzymes is the addition of GSH to electrophiles with a wide variety of chemical structures (Hayes and Strange, 2000).The GSTM1 and GSTT1 genes code for the cytosolic enzymes GSTM-mu and GST-theta, respectively. These enzymes are involved in the conjugation reactions in phase 2 metabolism of xenobiotics (Hayes and Pulford 1995) and in catalyzing reactions between glutathione and a variety of electrophilic compounds (Rushmore and Pickett 1993). It is thought that most GST substrates are xenobiotics or products of oxidative stress, including some environmental carcinogens (Hayes and Pulford, 1995). It has been postulated that the GST enzymes and the genes encoding these may be involved in susceptibility to cancer (Rebbeck, 1997).

DNA adducts in placenta of 98 mothers was studied in relation to metabolic genotype for glutathione Stransferase M1 (GSTM1) with different annual average air pollution levels (Topinka et al., 1997). They found that higher DNA adduct levels were detected in a group with GSTM1 null genotype. The relationships between the genotypes and the cytogenetic responses were evaluated in many studies among workers exposed to a complex mixture of pesticides ( Lecero et al., 2000 ; Xiao et al., 2003).

Mammalian glutathione S-transferase (GST) biotransformation of the widely used organophosphorus, methyl parathion (MeP) was investigated by Abel et al. (2004) in cytosolic fraction isolated from rat and mouse. They found no correlation between hGSTM1, hGSTT1 genotypes and MeP. Changes in erythrocyte deltaaminolevulinic acid dehydratase (ALA-D) after exposure to different pesticides and the effect of the combind polymorphism of enzymes involved in the detoxication of pesticides on the level of the target erythrocyte enzyme were studied as biomarkers of individual susceptibility (Hernandez et al., 2005). They found that ALA-D appears to be an important biological indicator of pesticide exposure and GSTT1 is relevant determinants of susceptibility to chronic pesticide.

The influence of the genetic polymorphisms of enzymes, GSTM1, GSTT1 using the polymerase chain reaction based genotyping method and micronucleus analysis on farm workers was studied and the obtained results showed significant differences in micronucleus and the polymorphic genes, GSTM1 and GSTT1, appeared to be associated with evaluated MN frequencies. Subjects lacking GSTT1 gene had the highest MN frequency when GSTM1 gene was concurrently missing (null) (Hammam, 2006).

\section{Materials and Methods}

\section{1 - Pesticide}

- Group: Organophosphorous

- Common name: Profenofos (Purchased from Kafer EL Zaiat Company, Egypt)

- Commercial name: Selian 72\% EC

- Chemical name: O-(4-bromo-2chloro phenyl) O-ethyl S-propyl phosphorothioate.

- Structure formula: $\mathrm{C} 11 \mathrm{H} 15 \mathrm{BrClO} 3 \mathrm{PS}$

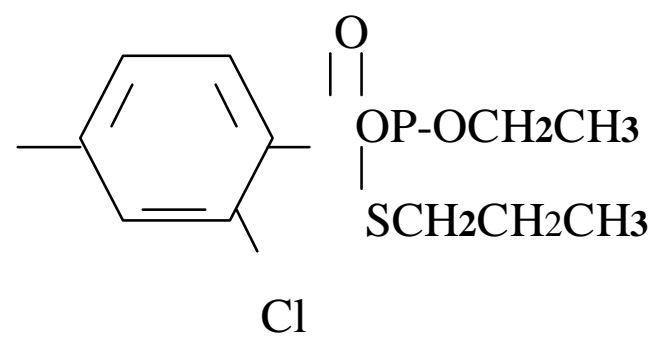

Experimental Animals:

Adult male albino rats, each weight about 150-200 grams were used in this study. They were housed in appropriate conditions, and allowed to acclimate the environment for two weeks prior to initiation of the study. All rats were caged, and allowed free access to food and water.

\section{Experimental protocol:}

Histopathological analysis:

Tissue samples:

The treated rats were sacrificed at the end of experimental period ( 28 days). The liver, kidneys, spleen and testes were 
dissected out and fixed in 15\% formalin and processed to get stained paraffin sections for the histological study (Drury et al. ,1967).

\section{Determination of cytogenetic assay}

\section{*Micronucleus assay:}

Micronucleus assay developed to assess the induction of chromosome damage is the test for production of micronuclei. The presence of micronucleated cells in polychromatic erythrocytes (PCE) is indicative to clastogenic activity. The micronuclei may be the results of a broken chromosome or chromatid which produces lagging anaphase fragment.

\section{Procedure}

The frequency of micronucleated erythrocytes in femoral bone marrow preparations was evaluated according to the procedure described by Schimid (1976), with some modifications recommended by Brusick (1978 and 1980) and Alder et al. (1991).

After the sacrifice of animals, both femurs were desiccated out, cleaned from muscular tissue and both cartilaginous epiphyses were cut off. The marrow was flushed out with $2 \mathrm{ml}$ fetal calf serum (FCS) into a centrifuge tube, using a clean syringe. The samples were centrifuged at $2000 \mathrm{rpm}$ for 5 minutes. Following centrifugation, the supernatant was discarded and the cells resuspended in a drop of FCS. The suspensions were spread on slides and air dried. The slides were fixed in methanol, stained in Wright stain followed by Giemsa stain, and rinsed in distilled water. A thousand of polychromatic erythrocytes (PCE) was scored. The frequency of micronucleated cells was expressed as percent of total polychromatic cells.
Glutathione S-transferase T1 (GSTT1) and Glutathione S-transferase M1 (GSTM1) polymorphisms :

\section{*Isolation of DNA from liver tissue:}

At the end of each treatment, animals were killed, and liver was removed, weighed and frozen at $-40^{\circ} \mathrm{C}$. Crude extraction of DNA from the liver tissue was obtained according to Hoffman-LaRoche (2001).

\section{The polymorphisms of GSTT1 and} GSTM1:

The genotypes of DNA rates liver samples were determined by polymerase chain reaction (PCR) based methods. PCR for the glutathione S-transferase (GSTM1 and GSTT1) was done according to the method describe by Norppa et al. (1995). The $\beta$-globin gene primer was included in the PCR reaction to confirm the presence of amplifiable DNA in the samples (Bell et al., 1995). PCR was carried out in a total volume of $25 \mu \mathrm{l}$, containing $10 \mu \mathrm{g}$ (500 ng) DNA; $10 \mathrm{Mm}$ dNTPs; $2.5 \mu 1$ 10x PCR buffer containing $\mathrm{MgCl} 2$. The samples were overlaid with $100 \mu \mathrm{l}$ white light mineral oil, heated to $97{ }^{\circ} \mathrm{C}$ for $10 \mathrm{~min}$ to denature DNA. The temperature was reduced to 63 ${ }^{\circ} \mathrm{C}$ for $1 \mathrm{~min}$ and primers $\mathrm{Ml}$ and $\mathrm{Tl}$ forward and reverse (50 Picomole) and $2.5 \mathrm{U}$ (5unit/ $\mu \mathrm{l}$ ) of $\mathrm{Taq}$ polymerase were added and heated at $72{ }^{\circ} \mathrm{C}$ for $1 \mathrm{~min}$. The reaction was then subjected to 35 cycles of amplification, $94{ }^{\circ} \mathrm{C}$ for $30 \mathrm{sec}, 59^{\circ} \mathrm{C}$ for $30 \mathrm{sec}$ and $72{ }^{\circ} \mathrm{C}$ for $45 \mathrm{sec}$. After 35 cycles, $15 \mu 1$ of PCR product were run on $2 \%$ agarose gel in Tris acetate EDTA (TAE) buffer and stained with ethidium bromide. The GSTT1 and GSTM1 negative genotypes were identified on the bases of the absence of the GSTT1 and GSTM1 specific DNA fragment. 
The PCR primers used were :

\begin{tabular}{|l|l|}
\hline PCR primers for GSTM1 gene & $\begin{array}{l}\text { (F) 5'ACC ATCCCT gAg AAA ATg AAgC 3' } \\
\text { (R) 5'CTT ggg CTC AAA gAT ACg gT 3' }\end{array}$ \\
\hline PCR primers for GSTT1 gene & $\begin{array}{l}\text { (F) 5' TCC TTA CTg gTC CCC ACA TCT 3' } \\
\text { (R) 5' TCA CTg gAT CAT ggT CAg CA 3' }\end{array}$ \\
\hline PCR primers for $\beta$-glubin gene & $\begin{array}{l}\text { (F)5'CAACTTCATCCACGTTCACC3' } \\
\text { (R)5'GAGCCAAGGACAGGTAC 3' }\end{array}$ \\
\hline
\end{tabular}

\section{Statistica analysis}

The obtained data were calculated and statistically analyzed using student's t-test according to Snedecor (1969).

\section{Results}

\section{Results of Micronucleus assay :}

The effect of profenofos insecticide on bone marrow of male rats was tested. Four male rats were taken after treatment with three doses 1/20, 1/40 and 1/80 LD50 (high, medium and low doses) and the number of the micronuclei was evaluated and compared with both negative control and ethyl methane sulfonate (EMS) as positive control. 4000 cells were examined per rat and the numbers of micronucleated PCE were counted and the data obtained are given in Table (1).

In the normal sample (negative control), 20 of micronucleated polychromatic erythrocytes $(P C E)$, cells were obtained among 4000 examined cells which represent $0.5 \%$, while in the EMS treatment (a positive control) 68 PCE cells were counted which represent $1.7 \%$. The treatment with 1/20 LD50 (high dose) of profenofos gave 92 PCE (among 4000 examined cells) with a percentage of $2.3 \%$, while 72 and 36 PCE cells were obtained after the treatment with the medium and low doses of profenofos (1/40 and 1/80 LD50), respectively which represent $1.8 \%$ and $0.9 \%$, respectively.

The obtained results showed that profenofos at all doses showed an increase in the frequency of micronucleated polychromatic erythrocytes. Also, the statistical
Analysis of these results indicated that the tested pesticide exerts high significant increase in the frequencies of micronucleated PCEM cells in the cases of high and medium doses, while the lowest dose produced significant increase in the number of PCEM cells when compared with negative control.

Table (2) summarizes the numbers and percentages of polychromatic erythrocytes (PCE) in bone marrow of male rats after the recovery period. The recovery results showed an increase in the frequency of micronucleated erythrocytes (PCE) in the three doses, when compared with the negative control. The obtained data showed a slight decrease in the number of micronucleus after stopping treatment when compared with the treated animals.

The micronucleui in PCEM in bone marrow of rats were shown in figs $(1,2)$.

\section{Results of GSTT1 and GSTM1 polymorphisms :}

In the present study, we have determined the distribution of the polymorphsmis of GSTT1 and GSTM1 genes using polymerase chain reaction (PCR) on animals exposed to the organophosphorous pesticides (profenofos) and referent non-exposed animals as control group.

Results of polymorphisms of both GSTT1 and GSTM1 showed positive genotype in control group. Also, the results of the GSTT1 genotyping in the treated rats (Fig 3) showed positive genotype in all doses of profenofos treatment. While the polymorphism of GSTM1 (Fig 5) showed positive genotype in the high and medium doses (1/20 LD50 and 1/40 LD50) of treatment except for polymorphism in the 
low dose (1/80 LD50) the results of GSTM1 was null (negative) genotype.

After recovery period the polymorphism of GSTT1 and GSTM1 (Figs 4 and 6) was found to be positive genotype, except the low dose (1/8 LD50 ) which showed null genotype for GSTM1 gene.

\section{Results of Histopathology:}

The results of histopathological examination of liver, kidney, spleen and tests revealed that profenofos exhibited pathological changes in these organs and considered as toxic substance even in its low doses. The microscopical examination of the liver showed massive, diffuse distructive and necrosed hepatocytes with infiltration of mononuclear inflammotary cells as well as severe congestion of the blood vessels and newly formed bile ductules (Fig 7 ) in dose of 1/20 LD50. The dose 1/40 LD50 of profenofos (Fig 8), showed the same pathological changes in the liver. The alternations in the liver tissue for the dose 1/80 LD50 of profenofos represented by moderate vacuolar degenerative changes of the hepatocytes with congested blood vessels and newly formed bile ductules with infiltration of mononuclear inflammatory cells (Fig 9).

The kidneys of the rats administrated profenofos at three doses level showed the same histopathological lesions which are represented by heamorrhages, periglome- rular edema, and some glomeruli were shrinkage. Also, necrosis of some cells lining the renal tubules was observed (Fig 10). In addition, in 1/80 LD50 of profenofos administrated rats, kidneys showed formation of renal cast in the lumen of the renal tubules (Fig 11).

The spleen of animals administrated with profenofos showed slight deplesion of the lymphocytes of the white pulp in all doses (Fig 12). The testes of rats showed severe edema which dispersed the seminiferous tubules away of each other (interstitial edema) in both $1 / 20$ and $1 / 40$ LD50 of profenfos treatment. Also, some seminiferous tubules showing severe necrosis of the spermatogenesis series cells (Fig 13). While the testes of 1/80 LD50 of profenofos administrated rats, showed severe necrosis of spermatogenesis series cells, with thickening of interstitial septa with infiltration of mononuclear inflammatory cells (Fig 14 ).

After stopping the treatment, slight regeneration was observed among the hepatocytes of the livers in $1 / 40$ or $1 / 80$ LD50 of profenofos represented by few mononuclear inflammatory cells and few hepatocytes showed vacuolar degenerative changes (Fig 15). The testes and kidneys showed the same pathological alternations as in the treated animals before stopping the treatment.

Table (1): Micronuclei in polychromatic erythrocytes (PCEM) in bone marrow of male albino rats treated with profenofos (Mean \pm STDER)

\begin{tabular}{|l|c|c|c|c|c|c|}
\hline \multirow{2}{*}{ Treatment } & \multirow{2}{*}{$\begin{array}{c}\text { Total NO. of } \\
\text { Examined } \\
\end{array}$} & \multicolumn{2}{|c|}{$\begin{array}{c}\text { Total No. of } \\
\text { cells }\end{array}$} & \multirow{2}{*}{$\begin{array}{c}\text { Total No. of } \\
\text { (PCEM) }\end{array}$} & Mean \pm SE & $\begin{array}{c}\text { \% Change } \\
\text { of } \\
\text { (PCEM) }\end{array}$ \\
\hline Negative control & 4000 & 8 & 12 & 20 & $5 \pm 0.58$ & 0.5 \\
\hline Positive control (EMS) & 4000 & 38 & 30 & 68 & $17 \pm 1.29$ & 1.7 \\
\hline 1/20 LD50 & 4000 & 48 & 44 & 92 & $23 \pm 0.58 * * *$ & 2.3 \\
\hline 1/40 LD50 & 4000 & 48 & 24 & 72 & $18 \pm 0.82 * * *$ & 1.8 \\
\hline 1/80 LD50 & 4000 & 16 & 20 & 36 & $10 \pm 0.82 * *$ & 0.9 \\
\hline
\end{tabular}

EMS: Ethyl methan sulfonate $(250 \mathrm{mg} / \mathrm{kg}$ b.wt)

$* * * \mathrm{P}<0.001$ : This difference is considerd to be very highly statistically significant 
Table (2): Micronuclei in polychromatic erythrocytes (PCEM) in bone marrow of male albino rats treated with profenofos after 14 days (recovery period) (Mean \pm STDER).

\begin{tabular}{|c|c|c|c|c|c|c|}
\hline \multirow[b]{2}{*}{ Treatment } & \multirow{2}{*}{$\begin{array}{c}\text { Total NO. } \\
\text { of } \\
\text { Examined } \\
\text { cells }\end{array}$} & \multicolumn{2}{|c|}{$\begin{array}{l}\text { Total No. of } \\
\text { (PCEM) }\end{array}$} & \multirow[b]{2}{*}{$\begin{array}{l}\text { Total No. of } \\
\text { (PCEM) }\end{array}$} & \multirow[b]{2}{*}{ Mean \pm SE } & \multirow{2}{*}{$\begin{array}{c}\text { \% Change } \\
\text { of } \\
\text { (PCEM) }\end{array}$} \\
\hline & & Big & Small & & & \\
\hline $\begin{array}{l}\begin{array}{l}\text { Negative } \\
\text { control }\end{array} \\
\end{array}$ & 4000 & 8 & 12 & 20 & $5 \pm 0.58$ & 0.5 \\
\hline 1/20 LD50 & 4000 & 40 & 26 & 66 & $16.5 \pm 1.26 * * *$ & 1.65 \\
\hline 1/40 LD50 & 4000 & 20 & 30 & 50 & $12.5 \pm 0.9^{* * * *}$ & 1.25 \\
\hline 1/80 LD50 & 4000 & 12 & 20 & 32 & $8.0 \pm 0.82 * *$ & 0.8 \\
\hline
\end{tabular}

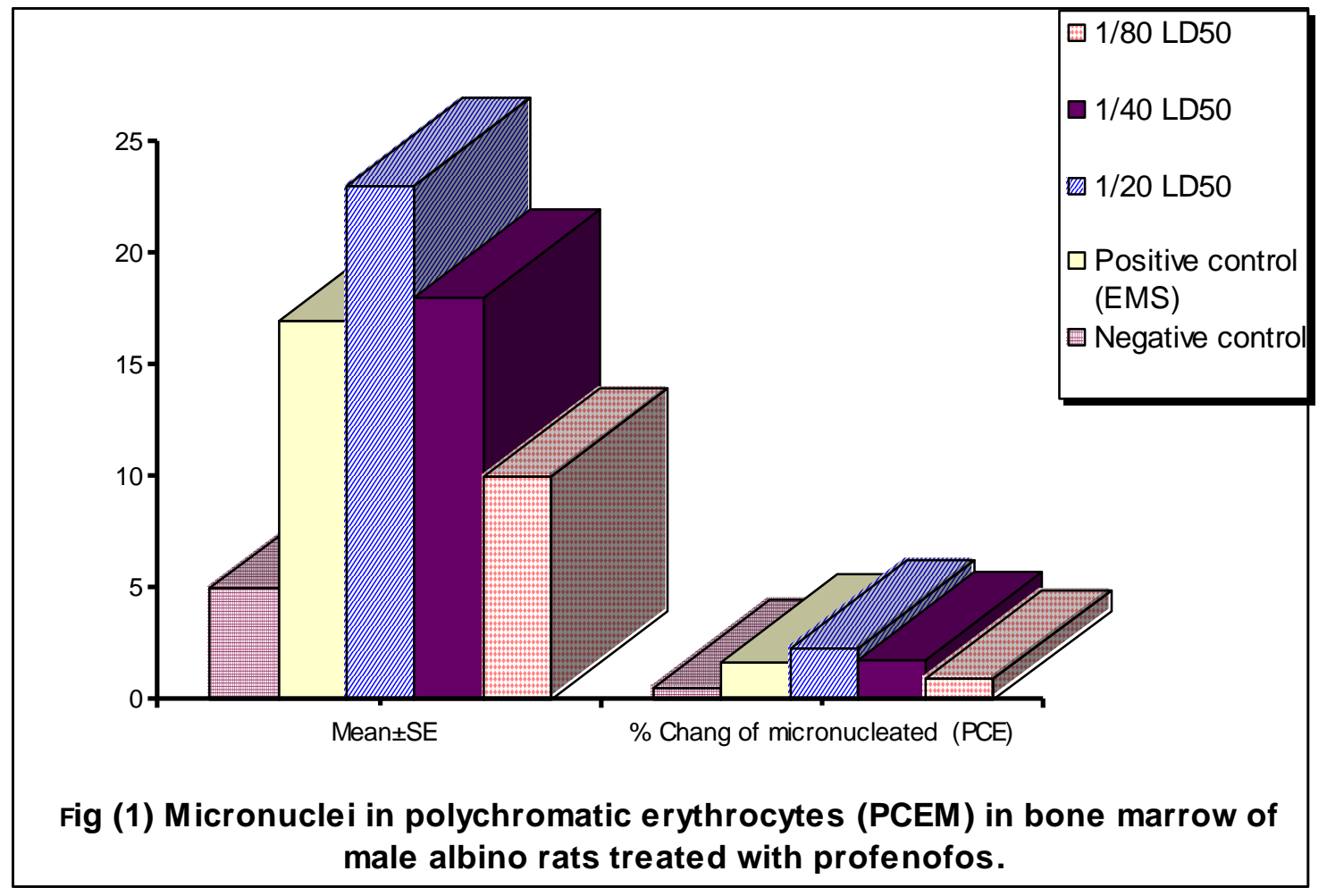


Studies of the Genotoxic and Histopathological................
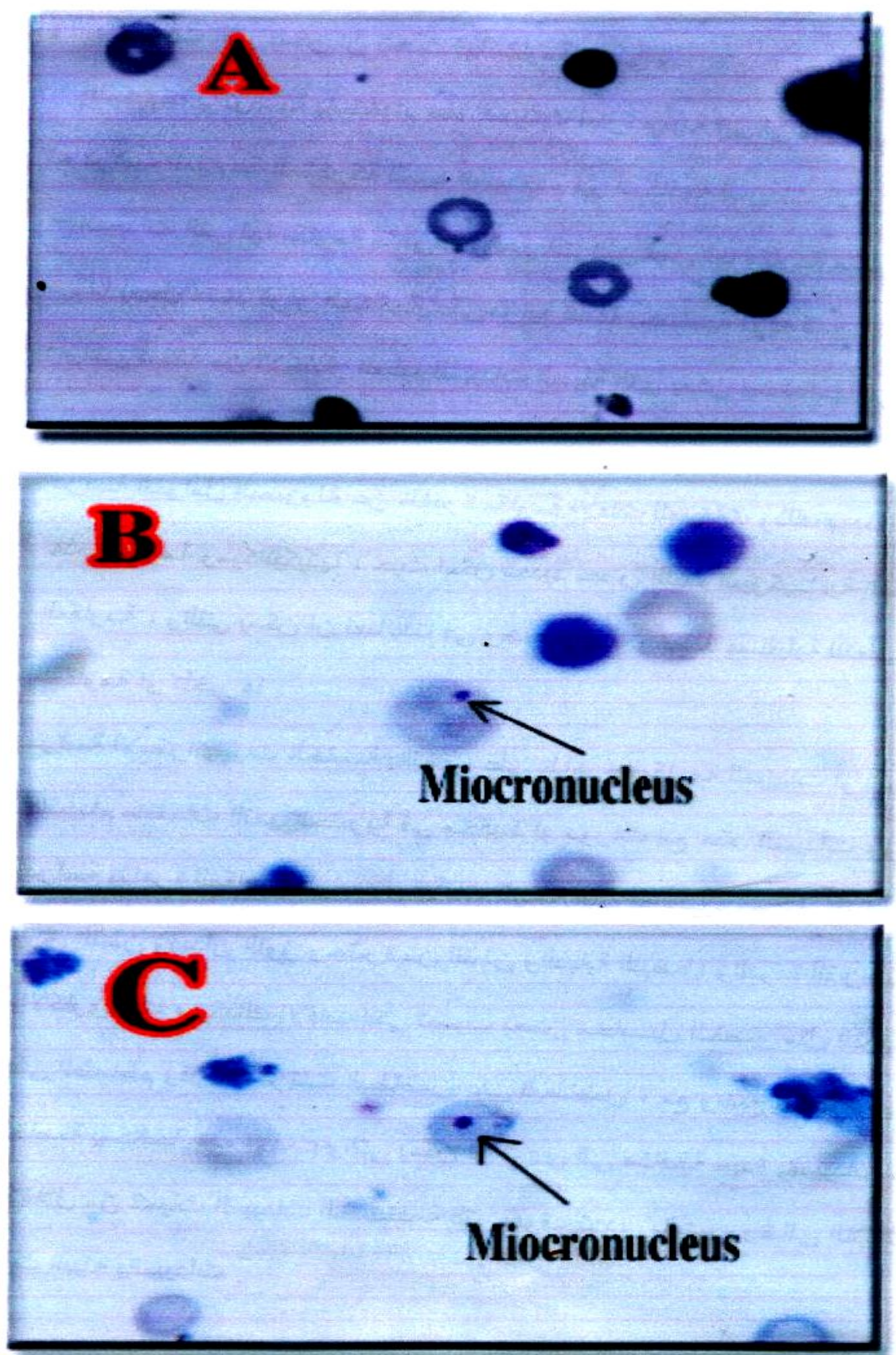

Fig (2) Micronuclei in polychromatic erythrocytes (PCEM) in bone marrow of rats treated with profenofos. 


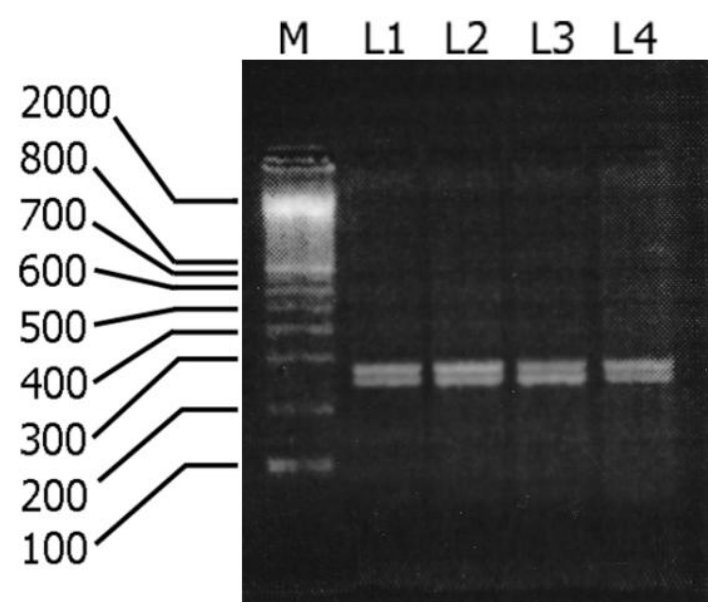

Fig (3): Agarose gel electrophoresis of PCR products of the GSTT1 polymorphism (M) DNA marker, (L1-L4). (L1) represents DNA patterns of control group, (L2-L4) represent DNA patterns of treated group (1/20 LD50 (High), 1/40 LD50 (Medium) and 1/80 LD50 (Low), respectively.

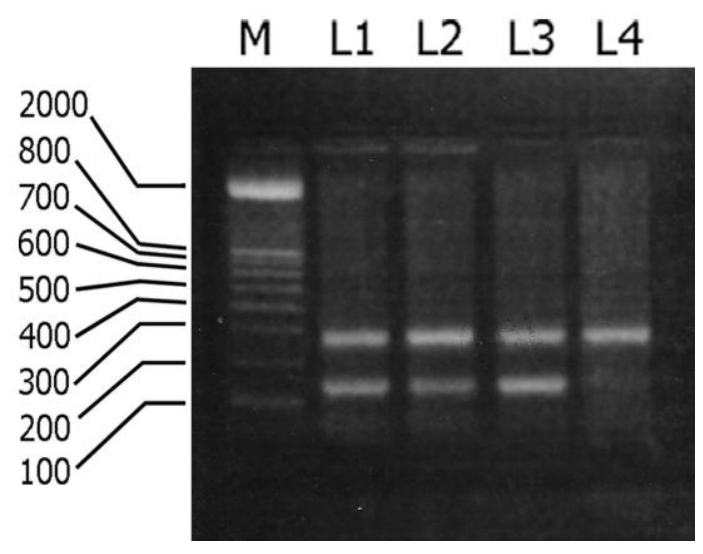

Fig (5) Agarose gel electrophoresis of PCR products of the GSTM1 polymorphism (M) DNA marker, (L1-L4). (L1) represents DNA patterns of control group, (L2-L4) represent DNA patterns of treated group (1/20 LD50 (High), 1/40 LD50 (Medium) and 1/80 LD50 (Low)), respectively.

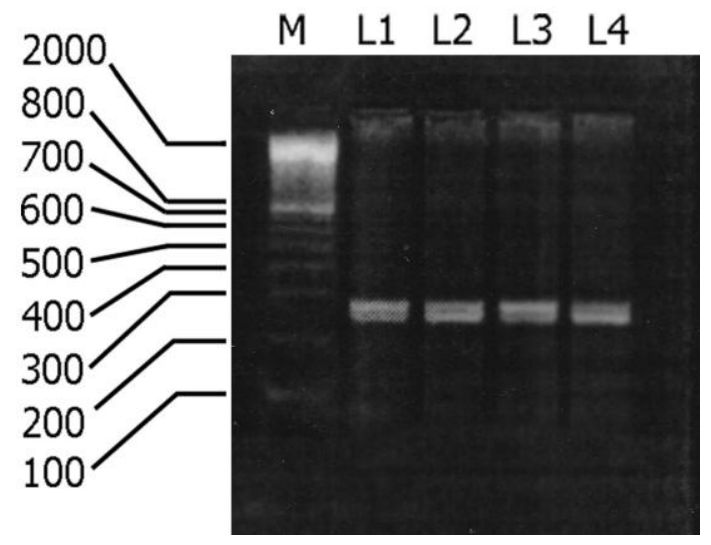

Fig (4): Agarose gel electrophoresis of PCR products of the GSTT1 polymorphism (M) DNA marker, (L1-L4).(L1) represents DNA patterns of control group,(L2-L4) represent DNA patterns of treated group (1/20 LD50 (High), 1/40 LD50 (Medium) and 1/80 LD50 (Low)), respectively after recovery period (14 days)

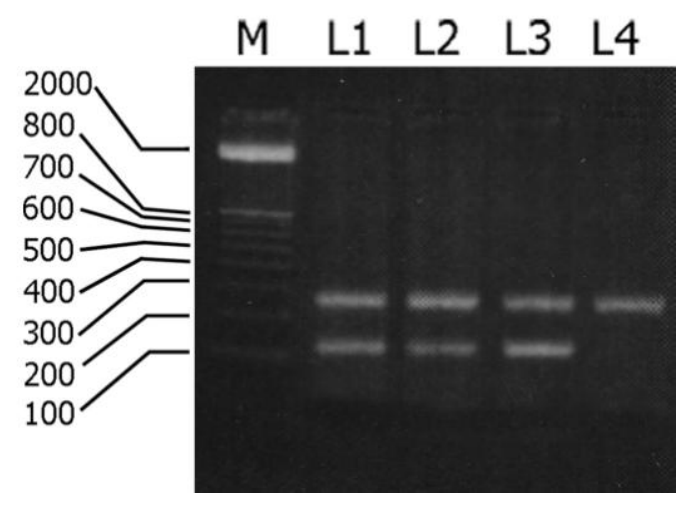

Fig (6) Agarose gel electrophoresis of PCR products of the GSTM1 polymorphism (M) DNA marker, (L1-L4). (L1) represents DNA patterns of control group, (L2-L4) represent DNA patterns of treated group (1/20 LD50 (High), 1/40 LD50 (Medium) and 1/80 LD50 (Low)), respectively after recovery period (14 days). 


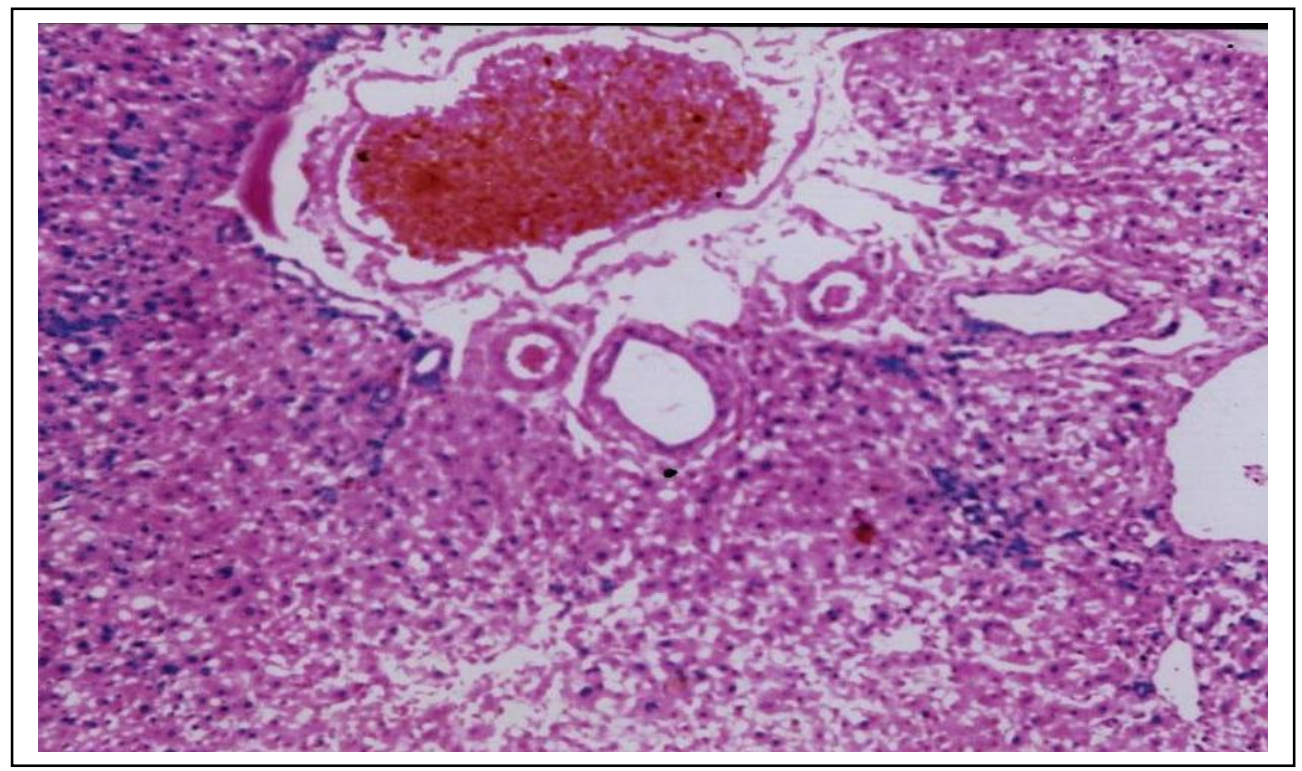

Fig (7): Liver of rat administrated 1/20 LD50 of profenofos showing, massive, diffuse destructive and necrosis of hepatocytes with infiltration of mononuclear inflammatory cells and congestion of blood vessels (H \& E. x 200).

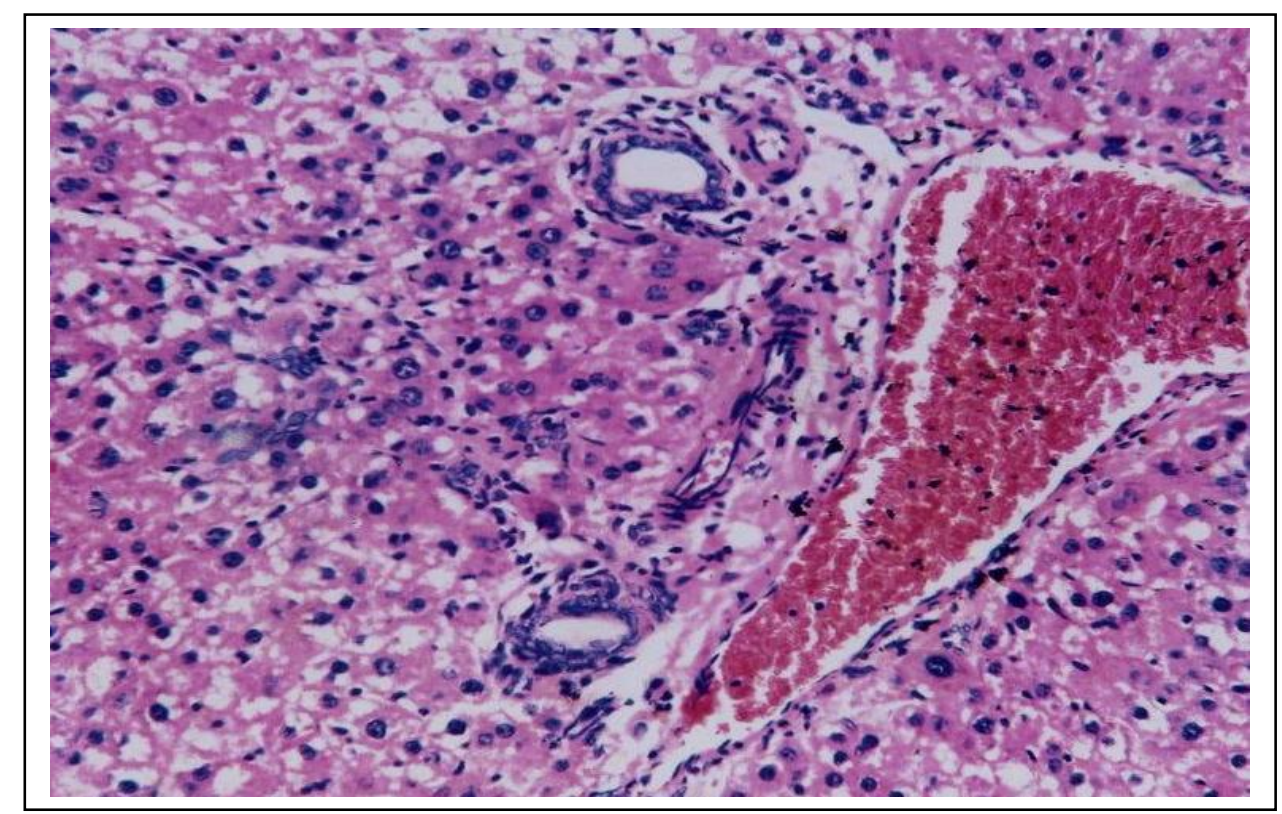

Fig (8): Liver of rat administrated 1/40 LD50 of profenofos showing congestion of blood vessels, newely formed bile ductules, infiltration of mononuclear inflammatory cells as well as vacuolar degenerative changes of hepatocytes (H \& E.X 400). 


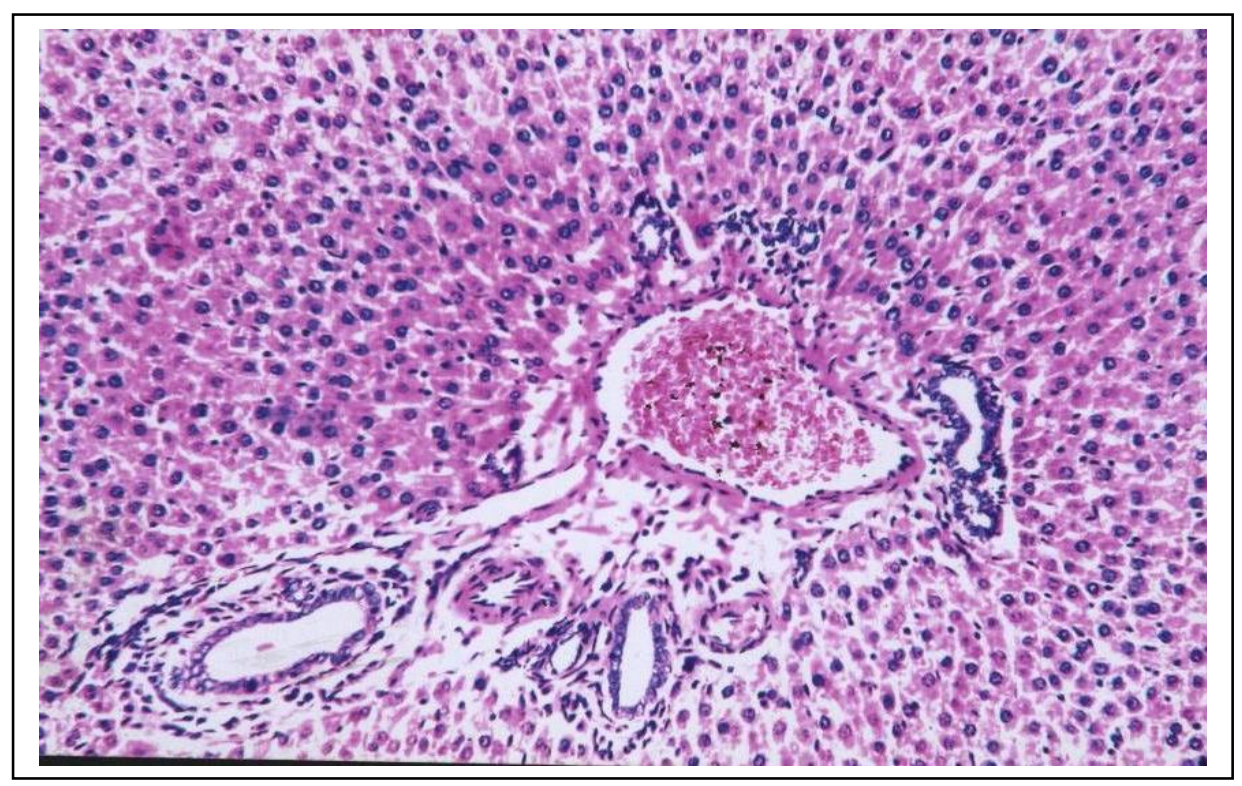

Fig (9): Liver of rat administrated 1/80 LD50 of profenofos showing congestion of blood vessels, newely formed bile ductules, few hepatocytes suffer from vacuolar degenerative changes (H \& E.X 400).

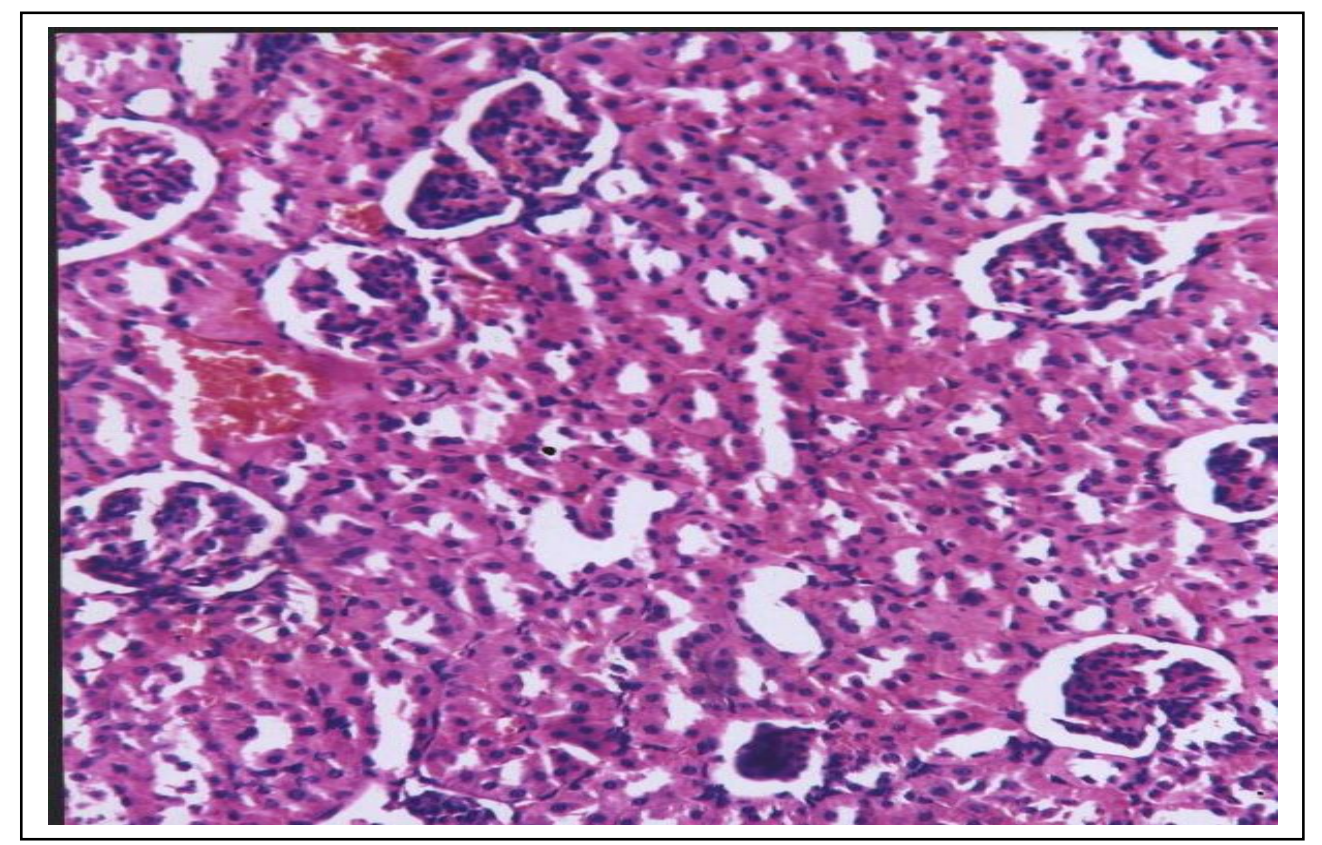

Fig (10): kidney of rat administrated 1/20 and 1/40 LD50 of profenofos showing heamorrhages, periglomerular edema, necrosis of some renal tubules lining cells (H \& E.X 200). 


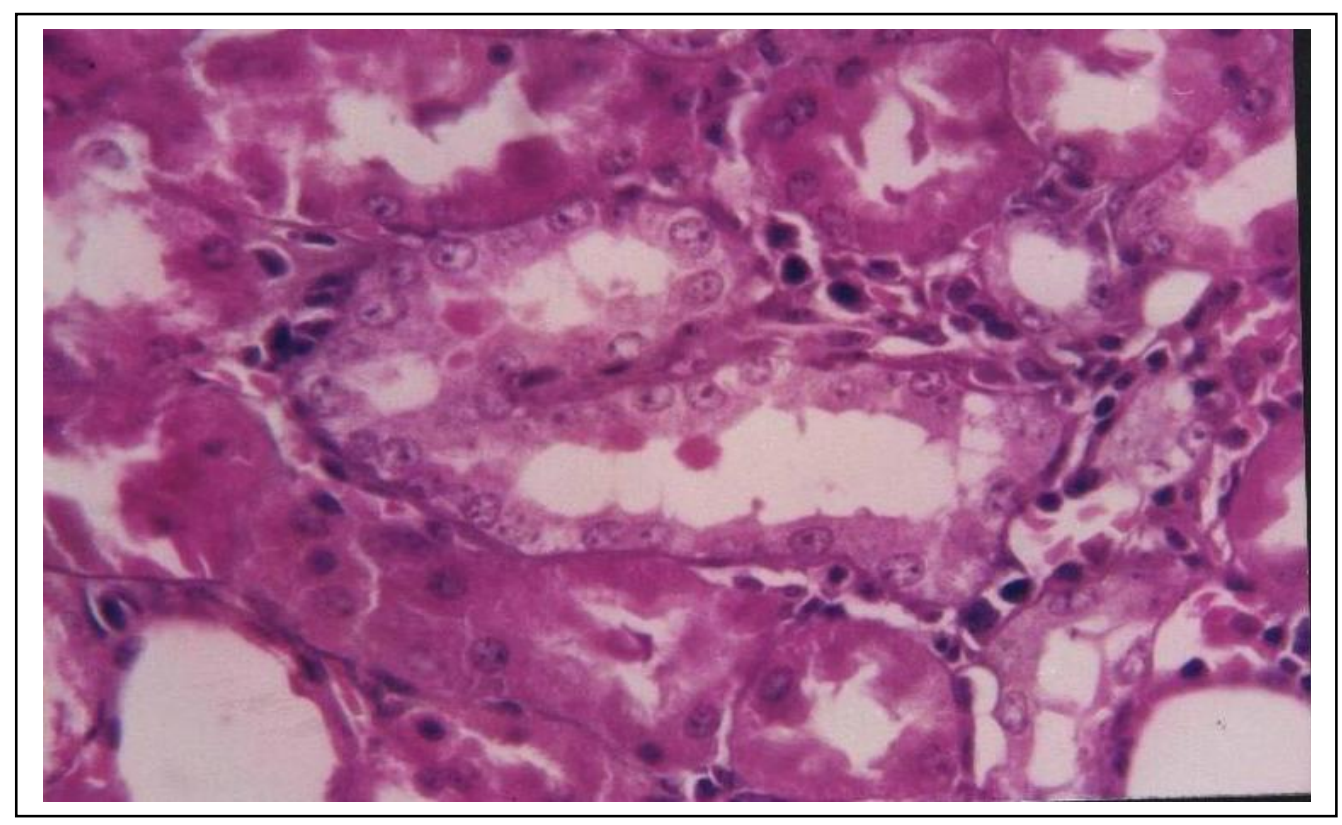

Error!

Fig (11): kidney of rat administrated 1/80 LD50 of profenofos showing formation of renal casts, infiltration of some inflammatory cells as well as necrosis of some renal tubules lining cells $(\mathrm{H} \& \mathrm{E}$. $\mathrm{x}$ 650).

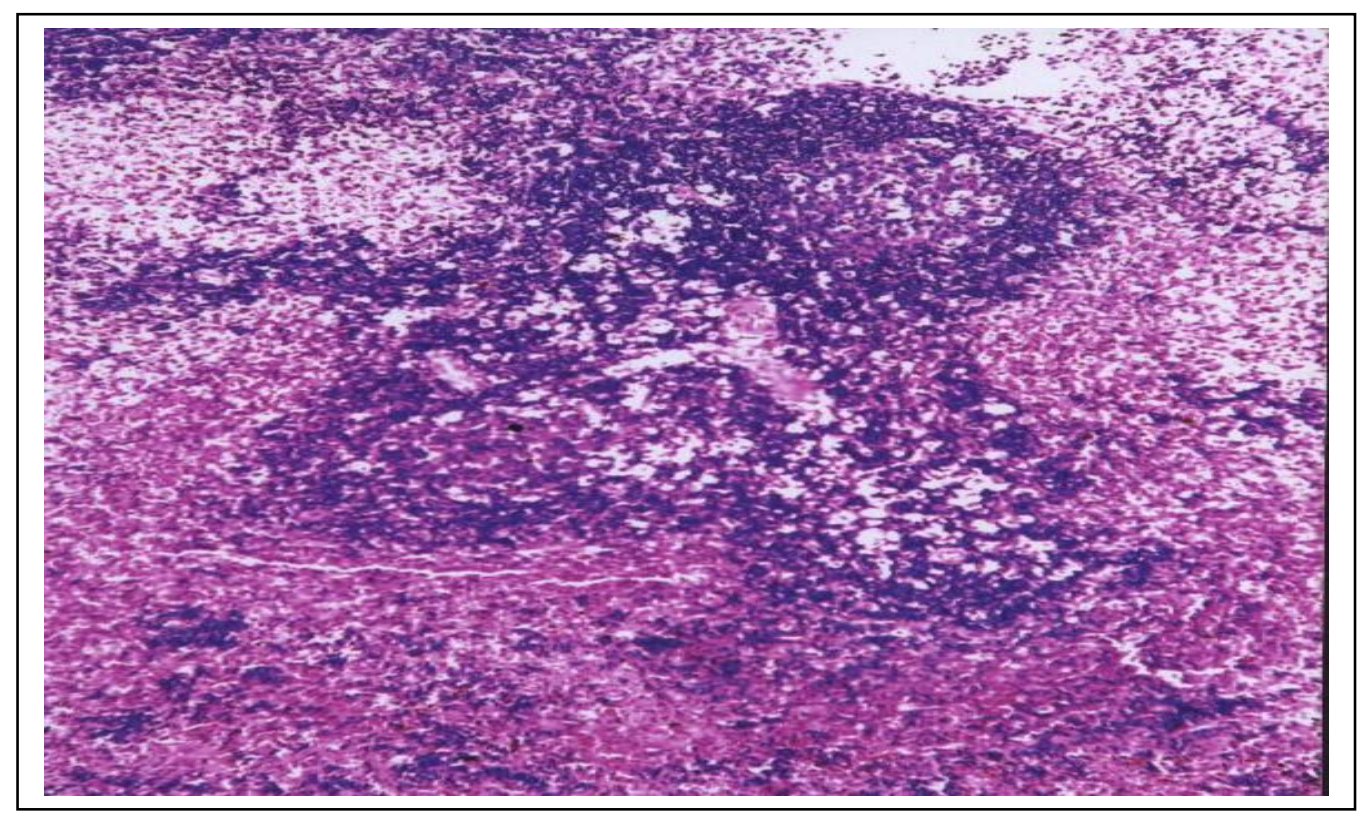

Fig (12): Spleen of rat administrated 1/20, 1/40 and 1/80 of profenofos showing slight deplesion of the white pulp (H \& E. $x$ 100). 


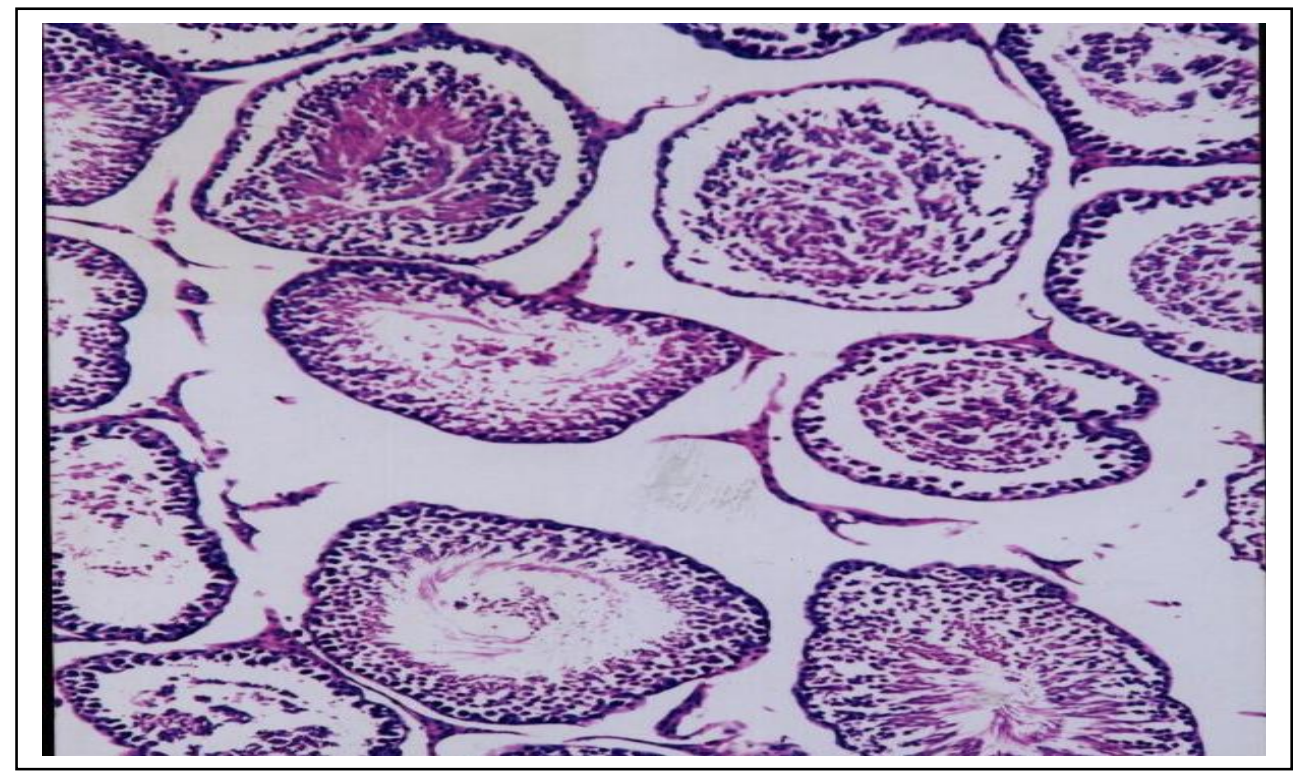

Fig (13): Testis of rat administrated $1 / 20$ and 1/40 LD50 of profenofos showing severE interstitial edema, a necrosis of spermatogenesis series cells lining the seminiferous tubules (H \& E.X 200).

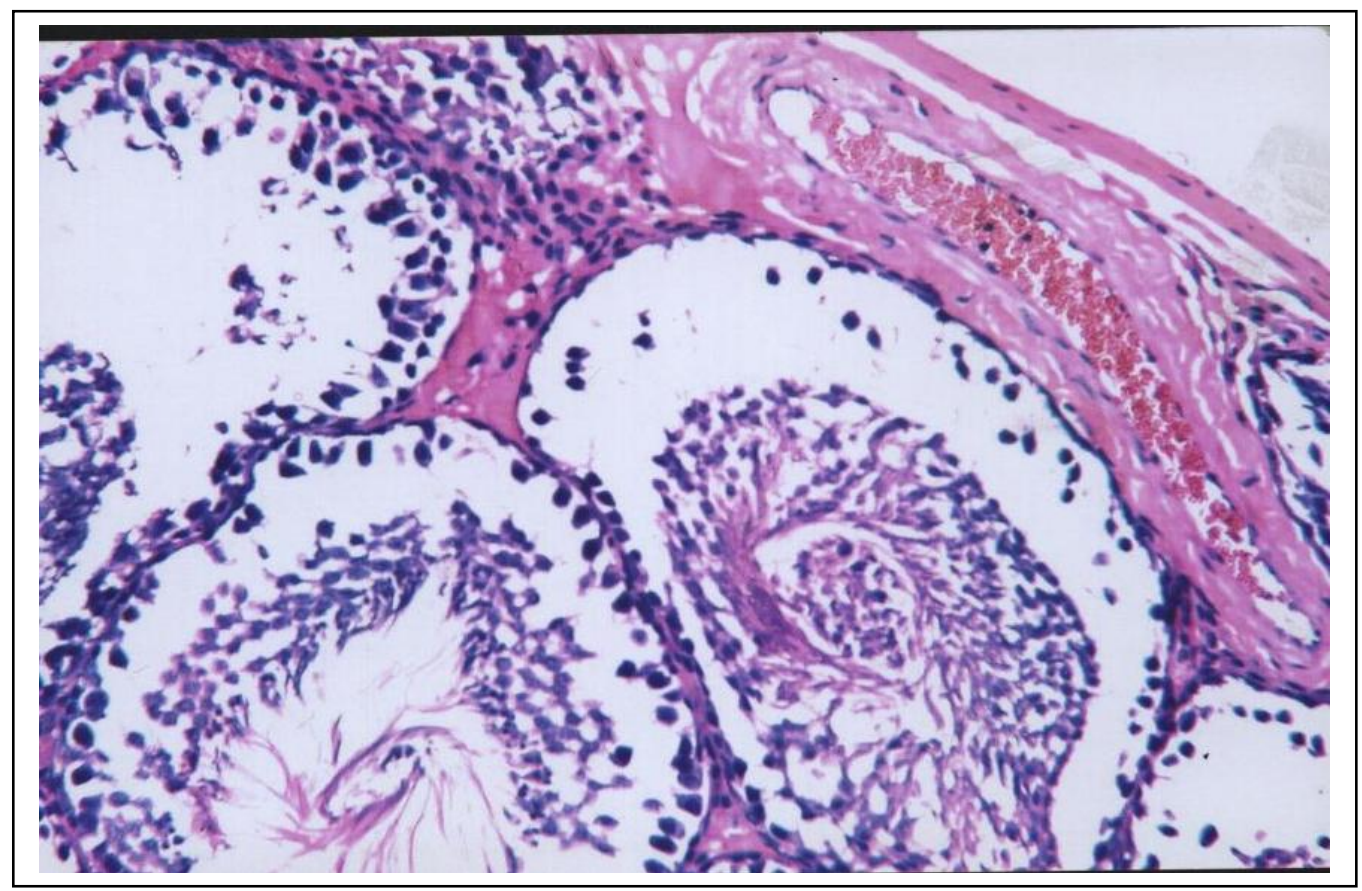

Fig (14): Testis of rat administrated 1/80 LD50 of profenofos showing severe necrosis of spermatogenesis series cells $\&$ congestion of blood vessels with thickening of the interstitial septa (H \& E.X 400). 


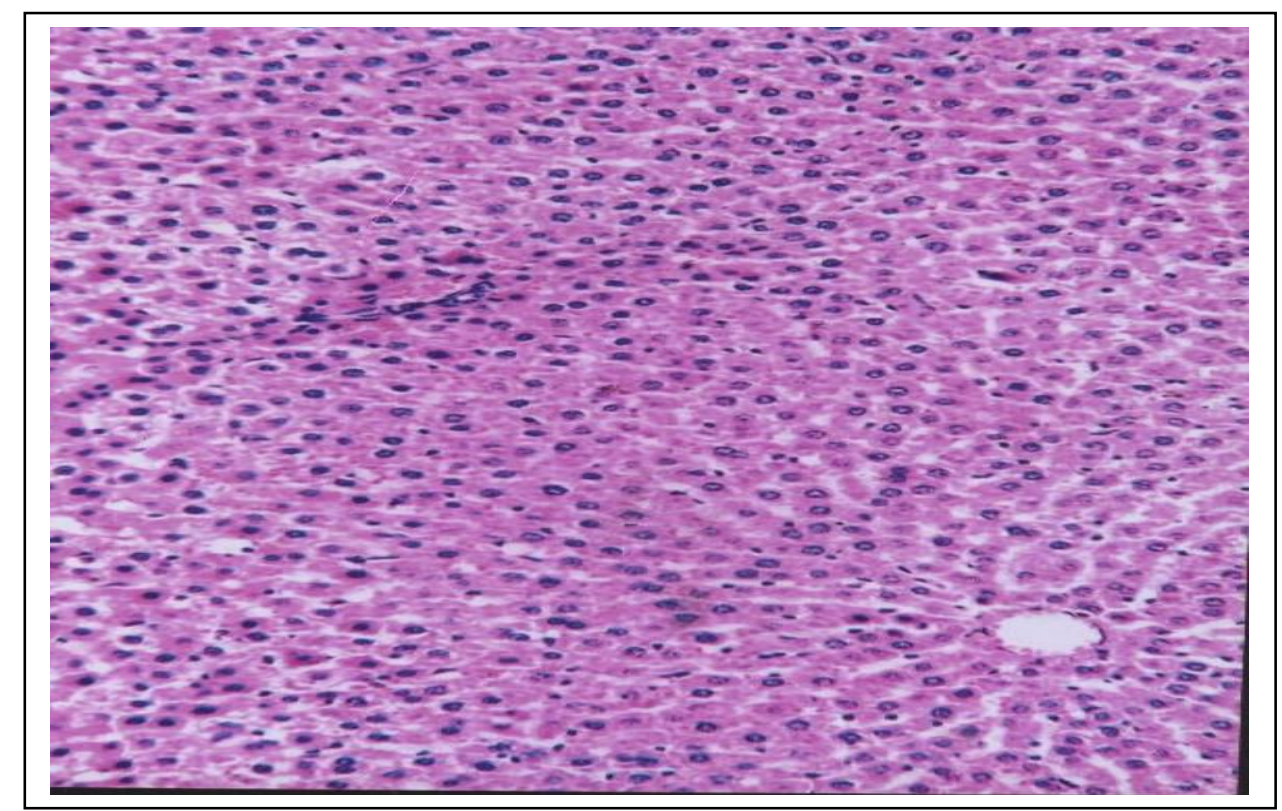

Fig (15): Liver of rat after recovery stages of $1 / 40$ and 1/80 LD50 of profenofos showing few inflammatory cells; few hepatocytes show vacuolar degenerative changes

(H \& E.X 200).

\section{Discussion}

Organophosphorous "OP" pesticides are rapidly replacing the organochlorine owing to the fast elimination of the former from the environment. However, this class of compounds "OP" is amongst the most toxic of those used by man (Cassia-Stocco et al., 1982). Organophosphorous pesticides occupy a prime position in pest management, due to their high insecticidal activity, their rapid metabolism, and their rapid decomposition in soil and water. Also, it was reported that organophosphate compounds are widely used in home and industry as pesticides, plasticizes, flame retardants and lubricants (Lieberman et al., 1998). They have very specific toxic effects; they are also neurotoxic, immunotoxic, and genotoxic. Organophosphorous compounds like profenofos are a powerful stomach poisons for most insects and are used on most crops such as alfalfa, cotton and maize (Ayyat et al., 2000).

The obtained results could be discussed under the follows subjects:-

\section{Genotoxic effects of the tested pesticides (micronucleus assay):}

The micronucleus test is considered one of cytogenetic test in this study where chromosome damages could be detected as a result of mutagenic effects of some chemical and physical agents. Sublethal proportions of agents that are mutagenic and carcinogenic to mammals interact with cellular DNA and are extremely potent in inducing chromosome damage, which may be detected cytologically. The cytological recognition of chromosome damage is limited to cells that undergo proliferation after exposure to the damaging agents.

The micronucleus test as applied to polychromatic erythrocytes in bone marrow of rodents is an efficient alternative to metaphase chromosome analysis for the detection of cytogenetic damage in-vivo in mammalian somatic cells (Heddle, 1973; Schimd, 1975; Heddle and Carrano, 1977; Jenssen and Ramel, 1978). The theoretical basis for micronuclei test is the hypothesis that broken chromosome or chromatid fragment may lag behind intact chromosome during the anaphase step of mitosis. During telophase, daughter nuclei are formed. If the broken and lagging chromatin is not included in the main nucleus during telophase, micronuclei are formed in the cytoplasm. Thus, it is believed that the frequency of cells containing micronuclei following chemical treatment is indicative of clastogenic 
activity. Since micronuclei may be the result of broken chromosomes or chromatids which produce lagging anaphase fragments. It is justifiable to assume that much of the chromatid damage not expressed after a single cell cycle e.g. (chromatid breaks) which will be missed in the micronucleus test using current protocols (Brusick, 1980).

The obtained data revealed that the treatment with profenofos at the three doses caused a significant increase in the frequencies of micronucleated polychromatic erythrocytes (PCEM). The percentage of PCEM cells were $2.3 \%, 1.8 \%$ and 0.9 in the high, medium and low doses respectively compared with $0.5 \%$ in the control group, table (1) . While the percentage of PCEM cells were $1.6 \%$, $1.25 \%$ and $0.8 \%$ in $1 / 20,1 / 40$ and $1 / 80$ LD50 in recovery groups after stopping the profenofos treatment respectively, table (2).

Similar findings were reported by Elkhatib and Shalaby (2001) on the effect of two pesticides : Alpha-cypermethrin (Synthetic pyrethroids) and diazinon (organophosphorus) on rat bone-marrow cells; Holland et al. (2002) on the effect of 2, 4- Dichlorophenoxy acetic acid (2, 4-D) herbicide on both whole blood and isolated lymphocytes; Hammam, (2004) on the effect of alpha-cypermethrin on rat bone marrow cells and Hammam and El-Khatib (2004) on the effect of diazinon on male rats, who reported the ability of organophosphorus to induce a significant increase in the frequency of micronucleated erythrocytes.

Organophosphorous pesticides are chemical alkylating agents and therefore could be mutagenic or carcinogenic (Chen et al., 1981). There is evidence that some organophosphorous pesticides may have invivo genetic effects, suggesting a possible link with cancer with long term or repeated heavy exposure (Hatjian et al., 2000). Also, Fenech (2000) stated that the micronucleus assay has emerged as one of the preferred methods for assessing chromosome damage because they enable both chromosome loss and chromosome breakage to be measured reliably. Similarly Bolognesi et al. (1993) studied micronuclei analysis on human population occupationally exposed to pesticides. They found a significant increase in micronucleated lymphocyte frequency in people occupationally exposed to pesticides. Our findings of increase in micronucleus frequency in bone marrow of rats indicate a potential hazard posed by pesticides exposure. This observation indicates once again the need to increase preventive measures in groups occupationally exposed to pesticides. These data are in line with several studies which reported a high prevalence of micronucleus frequency as a biomarker of chromosome damage (Bolognesi et al., 1993 ; Holland et al., 2002 ; Davies et al., 1998 ; Gomez-Arroyo et al., 2000). In agreement to our finding Liberman et al. (1998) reported that the organophosphorous compounds have very specific toxic effects; they are also neurotoxic, immunotoxic and genotoxic. Our results was explained by Kaur and Grover (1985) who reported that the chromatotoxic effects of organophosphorous pesticides might be attributed to their phosphorylating alkylating activity that is directly related to the electron affinity of the substituents. Also, TitenkoHolland et al. (1997) studied the cytogenetic effect of malathion (an organophosphorous pesticide) in exposed workers using the micronucleus assay in human lymphocytes. They found that the micronuclei were increased only at high doses approaching cytotoxic levels. Micornucleus evaluation could provide a measure of both chromosome loss and chromosome breakage and could assume the role of useful biomarker of risk for cancer (Bukvic et al., 2001). Our results revealed that profenofos produce a high frequency of $\mathrm{MN}$ cells as results to chromosome and DNA damage. The sensitivity and reliability of the micronucleus (MN) assay to detect DNA damage, as well as its capability when applied with different kinds of cells, make it a good method to analyze the potential cytogenetic damage of environmental pollutants (Surralles et al. 1992; KirschVolders et al. 1997 ; Przygoda et al. 1999). Thus, many studies have demonstrated the efficiency of the MN assay to detect DNA damage induced by pesticides (da Silva Augusto et al. 1997 ; Gomez-Arroyo et al. 2000). Our results in accordance to ElKhatib and Shalaby (2001) who studied the 
genotoxicity of diazinon as organophosphorous pesticide using the rat bone marrow cells chromosomal aberr-ations and micronucleus test. Their results revealed a significant increase in the micronucleus frequency in all of the treated groups compared with control. Also, Hammam and El-Khatib (2004) studied the genotoxic effect of diazinon on male rats using dipping and spraying method. The data showed that exposure to diazinon increases the frequency of chromosomal aberration and induction of micronuclei in bone marrow cells of rats when compared to negative control and the other treated group.

In conclusion, profenofos as one of organophosphorous pesticides induces high frequency of micronucleated cells $(P C E)$ in bone marrow of male rats. It is possible that this pesticide caused genetic damage. The results suggested that exposed workers living in the agriculture zones should be periodically examined to estimate any mutagenic effect which results from their contact with pesticides.

\section{Genetic polymorphisms for GSTT1 and GSTM1 genes in rats treated with profenofos pesticide:}

Xenobiotic enzymes genotypes were selected for this study because they are known to participate in metabolism of suspected or established carcinogens, and because polymorphisms of these genes have been associated with an increased cancer risk in adults (Pluth et al., 2000).

Results of polymorphisms of both GSTT1 and GSTM1 showed positive genotype in the control group. While the results of GSTT1 genotyping in the treated rats showed positive genotype in all doses of profenofos treatment. Also, GSTM1 showed positive genotype in high and medium doses (1/20 and 1/40 LD50) of treatment. After recovery period the polymorphism of GSTT1 and GSTM1 was found to be positive genotype in high and medium doses.

Of the genotypes studied, only the low dose (1/80 LD50) showed negative GSTM1 genotype at the end of profenofos treatment and the end of recovery period. A large variety of mutagens and carcinogen are present in the workplace, including industrial or man-made chemicals, pesticides, metals and fibres (Perera, 1993).These exposures are capable of supplementing or interacting with the preexisting "background" supplied by lifestyle (diet and smoking) and pollutants in the ambient environment. Human exposure patterns are complicated with respect to exposure to a single agent or complex mixtures (Anwar, 1994). Human exposure to pesticides has been associated with a variety of disease including cancer (Forget, 1991). Because of the potential environmental impact of pesticides and the large population potentially exposed, the effect of exposure to pesticides needs to be determined.

The deleted genotypes have been shown to be associated with susceptibility to mutagen-induced cytogenetic damage (Wincke et al., 1995), increased risk of asbestosis (Smith et al., 1994), and smoking associated bladder cancer and lung cancer (Hirvonen et al., 1993 ; Kihara and Noda, 1994). Also, up to $90 \%$ of all cancers are possibly caused by environmental factors such as tobacco smoking and occupational exposures (Yang et al., 1999). GST enzyme activity is known to be involved in pesticides detoxification (Hodgson et al., 1991), whereas glutathione conjugation has also been described in the metabolic activation of certain halogenated alkanes (Hallier et al., 1993). However, Hodgeston et al. (1991) stated that GST- mediated glutathione conjugation is known to play a role in the detoxification of several groups of pesticides. Little studies carried out on the influence of metabolic genotype on the frequency of $\mathrm{MN}$ in lymphocytes have given definitely positive results. In all these studies, MN frequency in farm workers subjects was similar to that of the control group (Pavanello and Clonfero, 2000). In an attempt to correlate the genotype of GSTT1 and GSTM1 on cytogenetic marker $(\mathrm{MN})$, the results of the present work revealed that there was higher frequency of $\mathrm{MN}$ in all the applied doses of profenofos (1/20, 1/40 and 1/80 LD50) after 28 days. This increase was not statistically significant with respect to the two genotype GSTT1 and GSTM1 among the treated and control animals.

In agreement with our results, no significant differences in spontaneous 
frequencies of SCE and MN attributed to the polymorphism of the GSTM1 gene has formerly been detected (Wiencke et al., 1990; Carstensen et al., 1993 ; Uuskula et al., 1995). On the other hand, at the end of treatment and the end of recovery period the low dose of profenofos (1/80 LD50) negative GSTM1 genotype (null) was shown which correlates with higher frequency of $\mathrm{MN}$ as marker of cytogenetic damage.

The elevated frequency of $\mathrm{MN}$ in GSTM1 null genotype in the low dose of profenofos treatment (1/80 LD50) may be explained by the loss of gene activity due to pesticides accumulation as genotoxins. In addition the animals treated with profenofos which had GSTM1 and GSTT1 positive genotype showed higher frequency of $\mathrm{MN}$, although the proper function of these genes was detoxification of the carcinogen and any genotoxins exposure through decreasing the cytogenetic damage, which was measured by the micronucleus induction. These results may be reasonable by the loss ability of GST gene to reduce the DNA damage due to long continuous exposure to pesticides as environmental pollutants.

In agreement with our study Flack et al. (1999) found increased micronucleus frequency in lymphocytes of greenhouse workers exposed to pesticides with respect to controls and their greater frequency in active (null) GSTM1 subjects. On the other hand, Scarpato et al. (1997) studied the correlation between cytogenetic damage in workers exposed to pesticides and controls. They found non significant relationship between $\mathrm{MN}$ and genotype status. Also, Lucero et al. (2000) studied the genotypes of GSTM1 and GSTT1 in workers exposed to pesticides. They found that $\mathrm{MN}$ frequency in exposed subjects was similar to that of control group and was not affected by the genotype of GSTT1 and GSTM1.

Many authors studied the relation between cytogenetic damage and the polymorphisms of GSTs gene. Van Poppel et al. (1993) reported that $\mathrm{MN}$ in sputum cells did not correlate with GSTM1 genotype of the smokers. AU et al. (1999); Cheng et al. (1999) reported positive results on indicators/genotype interaction for SCEs and genotype of GSTT1 and GSTM1. They found that the clearly protective role played by GSTT1 on SCEs in lymphocytes treated in- vitro with diepoxybutan, showed be noted when GSTT1 deleted subjects have increased SCEs levels. In addition, Norppa et al. (1995); Au et al. (1999) demonstrated an increase in biological indicators (CA, $\mathrm{MN}$ ) according to genotype influence. On the other hand, other study did not observe a correlation between the genotypes and cytogenetic damage (Pavanello and Clonfero, 2000).

Eventually, our data showed that the tested pesticides influences the MN frequencies of the treated animals at all dose levels and moderately interact with the genotypes of the genes studied. Taking into account the complexity of chemical exposures and the number and variability (polymorphisms) of carcinogen-metabolizing enzymes, assessment of one or two genotypes may not be sufficient to evaluate the risk for each individual or sub-groups. Thus, the polymorphism of GSTM1 and GSTT1 genotypes and micronucleus assay should routinely be determined in occupational exposure to environmental pollutants.

\section{References}

1- Abd El-Aziz Maii M (2004). Biochemical and genotoxic changes in white rats as exposed to Butachlor and thiobencarb herbicides. M.Sc. thesis, Faculty of Agriculture. Cairo University.

2- Alder I D, Kliesch U, Van Hummelen P and Kirsch-Volders M (1991). Mouse micronucleus test with known and suspect spindle poisons: results from tow laboratories. Mutagenesis, 6: 47-53.

3- Anwar W A (1994). Assessment of cytogenic changes in human population at risk in Egypt. Mutation Res., 313: 183-191.

4- Au W W, Torres Sierra C H and Salazarn C (1999): Cytogenetic effects from exposure to mixed pesticides and the influence from genetic susceptibility. Environ. Hlth. Perespect ., 107: 501-505.

5- Ayyat M S, Abd El-Monem U M, ElGendy $H \quad M$ and El-Fateh Hammad (2000): Profenofos effects on rabbit performance and their amelioration by using natural clay minerals. World Rabbit Science ., 8 (4) : 169-175.

6- Bell D A, Taylor J A, Butler M A, Stepfens F, Wiest J, Brubake L, Kadlubar F and Lucier G W (1993): 
Genotype/Phenotype discordance for human arylamine $\mathrm{N}$-acetyltransferase (NAT2) reveals a new slow-acetylated allele common in African-Americans. Carcinogenesis, 14: 1689 - 1712.

7- Bell D A, Taylor J A, Paulson D F, Robertson C N, Mohler J N and Lucier G W (1995): Genetic risk and carcinogen exposure: a common inherited detect of the carcinogen-metabolism gene glutathione Stransferase M1 (GSTM1) that increase susceptibility to bladder cancer. J. Nat. Cancer. Inst. 85: 1159-1164.

8- Bhalli J A, Khan Q M, Hag M A, Khjalid A $M$ and Nasim A (2006): Cytogenetic analysis of Pakistani individuals occupationally exposed to pesticides in a pesticide production industry. Mutagenesis , 21(2):143-8.

9- Bolognesi C, Parrini M, Bonassi S, Ianello $G$ and Salanitto A (1993): Cytogenetic analysis of a human population occupational exposed to pesticides. Mutation Res, 258: 239-249.

10- Brusick D J (1978): Alternations of germ cells leading to mutagenesis and their detection Environ. Health perspective , 24: 105-112.

11- Brusick D J (1980): Fundamentals of G T, Plenum Press, New-York, pp : 33-34.

12- Bukvic N, Gentile M, Susca F, Fanelli M, Serio G, Buonadonna L, Capurso A and Guanti G (2001): Sex chromosome loss, micronuclei, sister chromatid exchange and aging: a study including 16 centenarians. Mutation Res, 498: 159-167.

13- Carstensen U, Alexandrie A K, Hogstedt B, Rannug A, Bratt I and Hagmar L (1993): B- and T-lymphocytes micronuclei in chemistry sweeps with respect to genetic polymorphism for CYP1A1 and GST1 (class Mu). Mutation Res, 289: 187-195.

14- Cassia- Stocco R, Becak W, Gaeta R and Nazareth R M (1982): Cytogenetic study of workers exposed to methyl parathion. Mutation Res, 103: 71-76.

15- Chen H H, Hsueh J L, Sirianni S R and Huang C C (1981): Induction of sister chromatid exchanges and cell cycle delay in cultured mammalian cells treated with eight organophosphorous pesticides. Mutation Res, 88: 307-316.

16- Cheng T J, Hwang $\mathbf{S} \mathbf{J}$ and Kuo H V (1999): Exposure to epichlorohydrin and dimethylfomamide, glutathione Stransferase and sister chromatid exchange frequencies in peripheral lymphocytes. Arch. Toricol. 73: 282-287.

17- da Silva Augusto L G, Lieber S R, Ruiz $M$ A and De Souza C A (1997):
Micronucleus monitoring to assess human occupational exposure to organochlorides. Environ. Mol. Mutagen. 29: 46-52.

18- Davies H W, Kennedy S M, Teschke K and Quintana P J E (1998): Cytogenetic analysis of South Asian berry pickers in British Columbia using the micronucleus assay in peripheral lymphocytes. Mutation Res, 416: 101-113.

19- Drury R A B, Wallington $\mathbf{E} A$ and Cameron R (1967): Carleton's Histological Techniques. Fourth edition. New York: Oxford University Press.

20- D' Souza UJ, Zain A and Raju S (2005): Genotoxic and cytotoxic effects in the bone marrow of rats exposed to a low dose of paraquat via the dermal route. Mutation Res , 7 (1-2) : $187-190$.

21- El- Khatib E N and Shalaby Rokaya H (2001): Genotoxic effects of two pesticides and their mixture: In-vivo chromosomal aberrations and micronucleus assay. J. Union. Arab. Biol. Vol 16A: 355-380.

22- Fahmy GA and Darwish Fatma $M$ (2002) : Biochemical and pathological comparative results of fenitrothion and carbosulfan pesticides and their residuces in fat and meat of poultry. Vet Med J Giza , 50 (4) : $821-841$.

23- Fenech M (1993): The cytocynesis-block micronucleus teqnique: a detailed description of the method and its application to genotoxiciy studies in human populations. Mutation Res, 285: 35-44.

24- Fenech M (2000): The in-vitro micronucleus technique. Mutation Res, 455: 81-95.

25- Flack G C, Hirvonen A, Scarpato R, Saardcoski S T, Migliore $L$ and Norppa H (1999): Micronuclei in blood lymphocytes and genetic polymorphism for GSTM1, GSTT1 and NAT2 in pesticideexposed greenhouse workers. Mutation Res, 441: 225-237.

26- Forget G (1991): Pesticides and the third world. J. Toxicol. Environ. Hlth, 32: 11-31.

27- Gomez-Arroyo S, Diaz-Sanchez Y, Meneses-Perez M A, Villalobos-Pietrini $R$ and De Leon-Rodriguez $J$ (2000): Cytogenetic biomonitoring in a Mexican floriculture worker group exposed to pesticides. Mutation Res, 466: 117-124.

28- Gutierrez S, Carbonell E, Galofre P, Creus A and Marcos R ((1997): Micronuclei induction by I exposure: study in hyperthyroidism patient. Mutation Res, 373: 39-45.

29- Hallier E, Langhof T, Danappel D, Leubeehr M, Schroeder K R, Goergens H W, Muller A and Bolt H M (1993): 
Polymorphism of glutat-hione conjugation of methyl bromide-ethelen-oxid and dichloromethane in human blood: influence on the induction of sister chromatid exchanges (SCE) in lymphocytes, Arch. Toxicol., 67, 173-178.

30- Hammam Fatma M (2004): Genotoxic effects of alfa-cypermethrin in rat bone marrow cells: in-vivo chromo-somal aberrations and micronucleus assay. Egypt. J. Appl. Sci , 19 (3) : 667-691.

31- Hammam Fatma M (2006): Genetic polymorphisms for NAT2, GSTM1 and GSTT1 genes in Egyptian farm workers exposed to pesticides and micronucleus analysis in peripheral blood lymphocytes. J. Appl. Sci , 21 (8) : 248- 273.

32- Hammam Fatma $M$ and El-khatib E N (2004): Trial for minimization the antifertility action and the genotoxicity of diazinon to male rats by using the different patterns of dipping. Egypt. J. Appl. Sci , 19 (2) : 280-315.

33- Hatjian B A, Mutch E, Williams F M, Blain P G and Edwards J W (2000): Cytogenetic response without changes in peripheral cholinesterase enzymes following exposure to a sheep dip containing diazinon in-vivo and in-vitro. Mutation Res , 472(1-2): 85-92.

34- Hayes J D and Pulford D J (1995): The glutathion S-transferase supergene family: Regulation of GST* and the contribution of the isoenzymes to cancer chemoprotection and drug resistance. Critical Rev Biochem Mol Biol , 30: 445-600.

35- Hayes J D and Strange R C (2000): Glutathione-S-transferase polymorphisms and their biological consequence. Pharmacology 61: 154-166.

36- Heddle J A (1973): A rapid in vivo test for chromosomal damage. Mutation Res, 18: 187-190.

37- Heddle J A and Carrano A V (1977): The DNA content of micronuclei induced in bone marrow by gama- radiation evidence that micronuclei arise from a centric chromosome fragments. Mutation Res , 44: 63-69.

38- Hernandez A F, Lopez O, Rodrigo L, Gil F, Pena G, Serrano J L, Parron T, Alvarez J C, Lorente $\mathbf{J} A$ and Pla A (2005): Changes in erythrocyte enzymes in humans long-term exposed to pesticides: influence of several markers of individual susceptibility. Toxicol Lett , 15 : 159(1):1321.

39- Hirvonen A, Pursiainen-Husgafvel K, Anttila $S$ and Vanio $H$ (1993): The GSTM-1 null genotype as a potential risk modifier for squamous cell carcinoma of the lung. Carcinogenesis , 14:1479-1481.

40- Hodgson E, Silver I S, Butler L E, Lawton $M P$ and Levi $P$ E (1991): Metabolism. In Hayes WJ, Laws ER (eds): "Handbook of Pesticides Toxicology." Vol 1. San Diego: Academic Press, pp 107-167.

41- Hoffman-LaRoche A G (2001): Genomic DNA purification kit. $1335510^{\text {th }}$ Avenue North, Suite 120 Minneapolis. Minnesota 55441 USA.

42- Holland N T, Durmand P, Rothman N, Figgs L W, Blair A, Hubbard A and Smith M T (2002): Micronucleus frequency and proliferation in human lymphocytes after exposure to herbicide 2,4-dichlorophenoxyacetic acid in-vitro and in-vivo. Mutation Res, 521: 165-178.

43- Iarc (1991): Monograph on the evaluation of carcinogenic risks to human, vol. 53, occupational exposures in insecticide application, and some pesticides. International agency for research on cancer , Lyon : $53-70$.

44- Jenssen D and Ramel C (1978): Factors affecting the induction of micronuclei at low doses of x-rays, MMS and dimethylnitros amine in mouse erythrocytes. Chromosoma, 74: 299-305.

45- Kihara M and Noda A K (1994): Lung cancer of gstm1 null genotype is dependent on the extent of tobacco smoke exposure. Carcinogenesis , 15: 415-418.

46- Kirsch-Volders M, Elhajouji A, Cundari E and Van Humelen $P$ (1997): The in vitro micronucleus test: a multi-endpoint assay to detect simultan-eously mitotic delay, apoptosis, chromosome breakage, chromosome loss and non-disjunction. Mutation Res, 392: 19-30.

47- Lieberman A D, Craven M R, Lewis H A and Nemanzo J H (1998): Genotoxicity from domestic use of organophosphate pesticides. J. Occup. Env. Med , 40:954957.

48- Lucero L, Pastor S, Suarez S, Durban R, Gomez C, Parron T, Creus A and Marcos A (2000): Cytogenetic biomonitoring of Spanish greenhouse workers exposed to pesticides: micronuclei analysis in peripheral blood lymphocytes and buccal epithelial cells. Mutation Res, 464:255-262.

49- Miller M S, McCarver D G, Bell D A, Eaton D L and Goldstein J A (1997): Genetic polymorphisms in human metabolic enzymes. Fundam. Appl. Toxicol , 40: 1 - 14 .

50- Norppa H, Hirvonen A and Jarventaus H (1995): Role of GSTT1 and GSTM1 genotypes in determing individual 
sensitivity to by diepoxybutan in cultured human lymphocytes. Carcinogenesis , 16: 1261-1264.

51- Pastor Susana Gutierrez Sara Creus A, Cebulska-Wasilewska A. and Marcos R (2001): Micronuclei in peripheral blood lymphocytes and buccal epithelial cells of polish farmers exposed to pesticides. Mutation Res , 495: 147-156.

52- Pavanello S and Clonfero E (2000): Biological indicators of genotoxic risk and metabolic polymorphisms. Mutation Res, 463: 285-308.

53- Perera F (1993): Biomarkers and molecular epidemiology of occupationally related cancer. J. Toxicol. Environ. Health , 40 (2-3): 203-15.

54- Pluth J M, Ramsey M J and Tucker J D (2000): Role of maternal exposures and newborn genotypes on newborn chromosome aberration freque-ncies. Mutation Res , 465: 101-111.

55- Przygoda R T, Mckee R H, Amoruso M A and Freeman J J (1999): Assessment of the utility of the micronucleus test for petroleum-derived materials. Mutation Res , 438: 145-153.

56- Rebbeck T R (1997): Molecular Epidemiology of the human glutathion Stransferase genotypes GSTM1 and GSTT1 in cancer susceptibility. Cancer Epidemiology, Biomarkers \& Prevention , 6: 733-43.

57- Rushmore T H and Pickett C B (1993): Glutathion S- transferases, Structure, regulation, and therapeutic implications. Biolog Chemistry, 268: 11475 11478.

58- Scarpato R, Hirvonen A, Migliore L, Flack G and Norppa H (1997): Influence of GSTM1 and GSTT1 polymorphisms on the frequency of chromosome aberrations in lymphocytes of smokers and pesticidesexposed greenhouse workers. Mutation Res, 389: 227-235.

59- Schmid W (1975): The micronucleus test. Mutation Res , 31: 9-15.

60- Schmid W (1976): Chemical mutagen testing on in vivo somatic mammalian cells. Agents Actions, 3: 77-85.

61- Snedecor G W (1969): "Statistical method" Aiwa State Univ. Press. Ames., USA. Fourth Edition.

62- Smith C M, Kelsey K T, Wincke J K, Leyden K, Levin S and Christiani D C (1994): Inherited glutathione S-transf-erase deficiency is a risk factor for pul-monary asbestosis. Cancer Epid-emiol.Biom. Prev, 3: 471-477.
63- Surralles J, Carbonell E, Marcos R, Degrassi F, Antoccia A and Tanzarella C (1992): A collaborative study on the improvement of the micronucleus test in cultured human lymphocytes. Mutagenesis, 7: 407-410.

64- Surralles J, Autio K, Nylund L, Jarventaus H, Norppa H, Veidebaum T, Sorsa $M$ and Peltonen K (1997): Melecular cytogenic analysis of buccal cells and lymphocytes from benzene exposed workers. Carcinogenesis , 18: 817823.

65- Titenko-Holland N, Moore $\mathbf{L} \mathbf{E}$ and Smith MT (1994): Measurement and characterization of micronuclei in exfoliated human cells by florescence in situ hybridization with a centromic probe. Mutation Res, 312: 39-50.

66- Titenko-Holland N, Windham G, Kolachana P, Reinisch F, Parvatham S, Osorio A M and Smith A M (1997): Genotoxicity of malathion in human lymphocytes assessed using the micronucleus assay in vitro and in vivo: A study of malathion-exposed workers. Mutation Res, 388: 85-95.

67- Topinka J Binkova B, Mrackova G, Stavkova Z, Peterka V, Benes I, Dejmek J, Lenicek J, Pilcik T and Sram R J (1997): Influence of GSTM1 and NAT2 genotypes on placental DNA adducts in on environmentally exposed population. Environmental and Mol. Mutagenesis , 30: 148-195.

68- Uuskula M, Jarventaus I H, Hirvonen A, Sorsa $M$ and Norppa H (1995): Influence of GSTM1 genotype on sister chromatid exchang induction by styrene-7,8-oxide and 1,2-epoxy-3-butene in cultured human lymphocytes. Carcinogenesis, 16: 947-950.

69- Van Poppel G, Verhagen H, Veer $P$ and Van Bladeren P J (1993): Markers for cytogenetic damage in smokers: associations with plasma antioxidants and glutathione S-transferase. Cancer Epidemiol. Biom. Prev. 2: 441-447.

70- Wiencke J K, Kelsey K T, Lamela R S and Toscano W A (1990): Human glutathione S-transferase deficiency as a marker of susceptibility to epoxide-induced cytogenetic damage. Cancer Res , 50: 15851590.

71- Wild D (1978): Cytogenitec effect in the mouse of 17 chemical mutagens and arcinogens evaluated by micronucleus test . Mutation Res , 56, 319-327.

72- Wincke, J K, Pemble S, Ketterer B and Kelsey K T (1995): Gene deletion of 
Fatma M. Hammam \& Eman M. Abd el Mottaleb

glutathione S-transferase theta: correlation with induced genetic damage and potential role in endogenous mutagenesis. Cancer Epidemiol. Biom, Prev. 4: 254-259.

73- Xiao C, He F S, Zheng Y X, Leng S G, Qin F K, Niu Y and Shi Q L (2003): Genetic susceptibility to intermediate myasthenia syndrome following ganophosphate insecticides poisoning. Zhonghua Yu Fang Yi Xue Za Zhi , 37(4):259-62.
74- Yang M, Koga $M$, Katoh $T$ and Kawamoto T A (1999): Study for the proper application of urinary naphthols. New biomarkers for airborne polycyclic romatic hydrocarbons. Arch, Environ. Contam. Toxicol , 36: 99-108.

75- Zhou P, Liu B and Lu Y (2005): DNA damaging effects of carbosulfan and its main metabolites on mice by micronucleus test and single cell gel electrophoresis. Sci China C Life Sci , 48 ( 1) : 40-7. 


\section{دراسات على التأثير السمى الوراثى والهـتوباثولوجى لمبيا البروفينوفوس على الجرذانيز البهان البيضاء فاطمة محمد همام , إيمان عبد الجدان البمطاع المبلب}

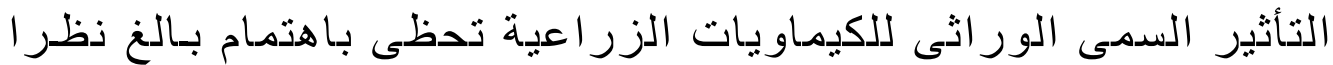

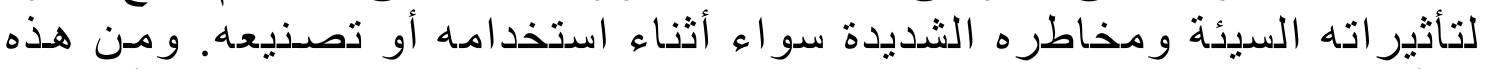

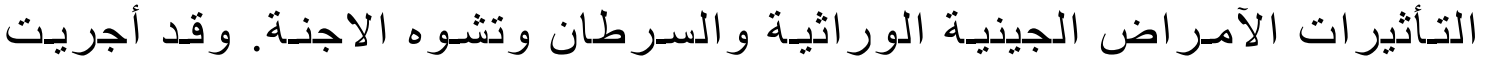

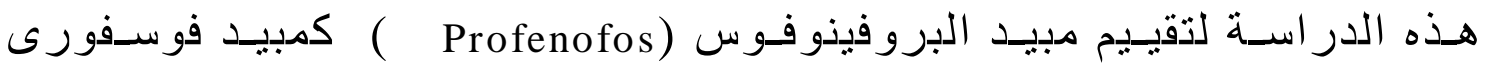

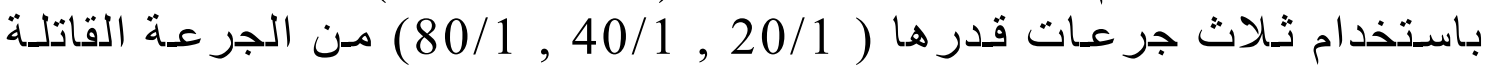

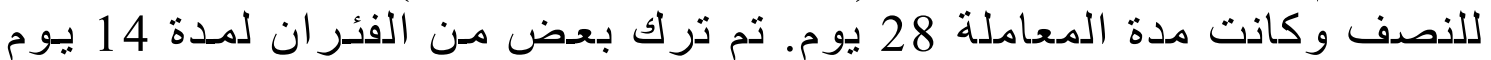

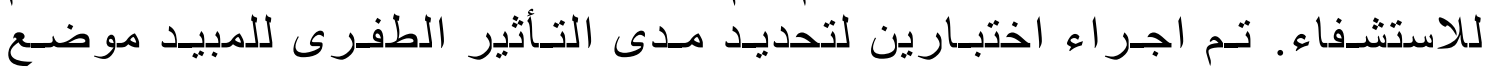

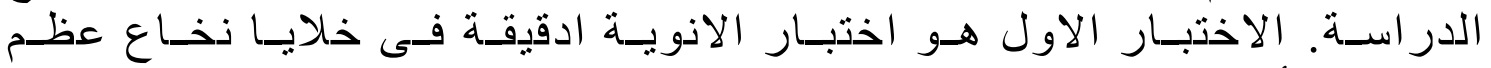

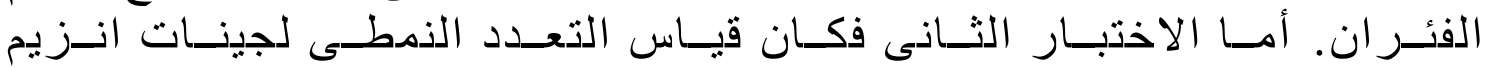

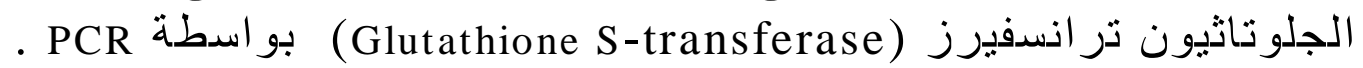

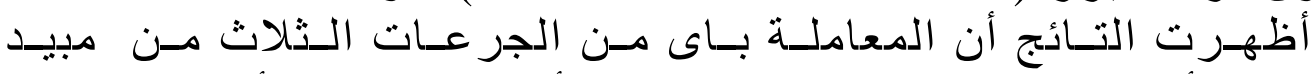

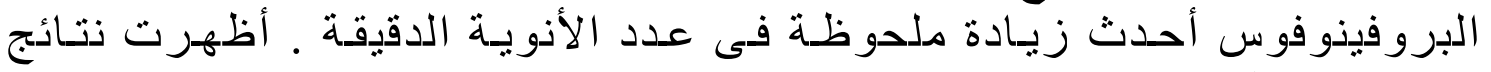

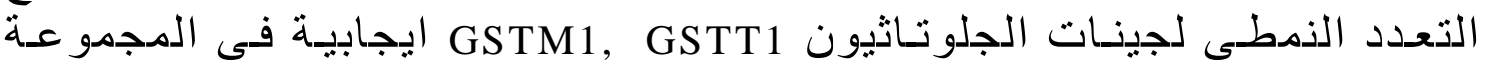

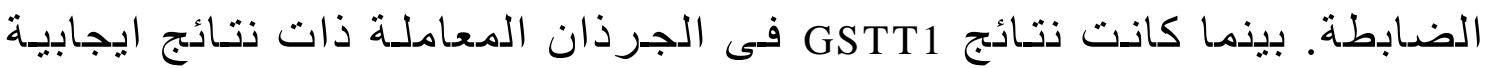

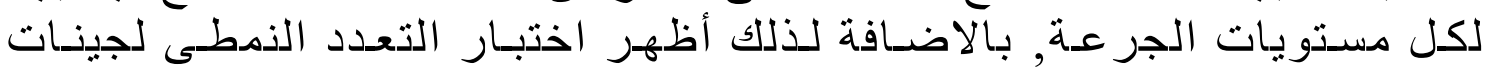

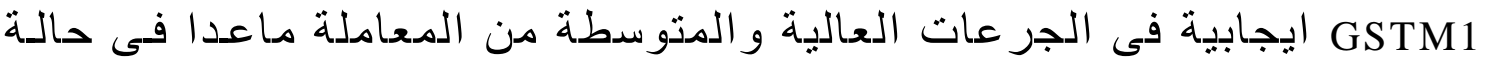
الجر عة المنذفضة حيث كانت الت الته النتيجة سلبية.

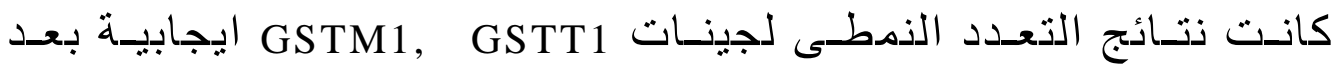

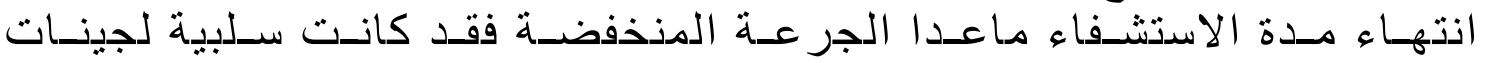
GSTM1

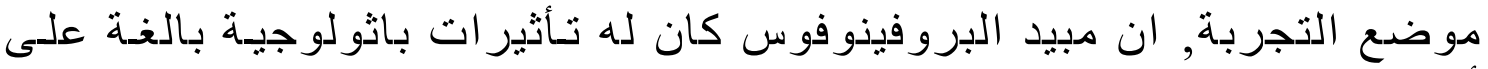

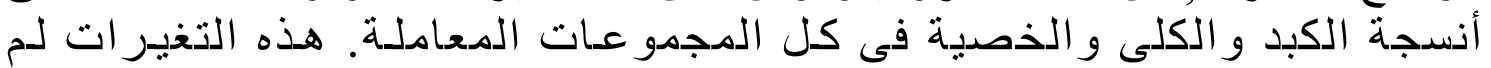

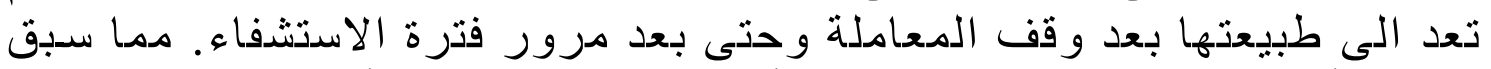

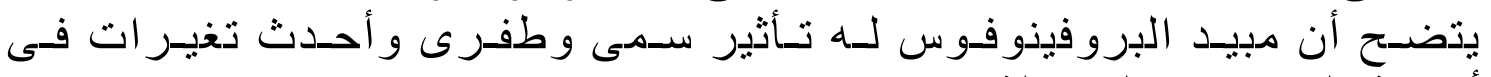
أنسجة الحيو ان مبنات الدعاملة. 